\title{
Validation of the Enterococci indicator for bacteriological quality monitoring of beaches in Malaysia using a multivariate approach
}

\author{
Asmat Ahmad ${ }^{1 *}$, Ayokunle C Dada ${ }^{1,2^{*}}$, Gires Usup ${ }^{3}$ and Lee $Y$ Heng ${ }^{4}$
}

\begin{abstract}
There is currently no established bacteriological beach quality monitoring (BQM) program in place in Malaysia. To initiate cost-effective, sustainable bacteriological BQM schemes for the ultimate goal of protecting public health, policy decision makers need to be provided robust, indigenous empirical findings that validate appropriate water quality parameters for inclusion in such monitoring programs. This is the first study that assesses the validity of enterococci as an ideal indicator for bacteriological BQM in Malaysia using a multivariate approach. Beach water and sand samples from 7 beach locations were analyzed for a total of twenty-one microbial and non-microbial water quality parameters. A multivariate approach incorporating cluster analyses (CA), principal component analyses (PCA), and factor analysis (FA) was also adopted. Apart from the weak correlations of Staphylococcus aureus with concentrations of Vibro species $(r=0.302, p=0.037)$ and total coliforms $(r=0.392, p=0.006)$ in seawater, no correlation existed between $S$. aureus concentration and other parameters. Faecal coliforms failed to correlate with any of the tested parameters. Enterococci also correlated with more quality parameters than faecal coliforms or any other indicator. Multiple linear regressions highlighted a significant, best fit model that could predict enterococci concentrations in relation to other parameters with a maximum predictive success of $69.64 \%$. PCA/FA clearly delineated enterococci and faecal coliforms as parameters that weighed strongly for BQM while Staphylococcus aureus, faecal coliforms and enterococci weighed strongly for beach sand quality monitoring. On the whole, higher correlations of enterococci levels with other parameters than was observed for faecal coliforms suggest that the former be considered a preferred parameter of choice for BQM in Malaysia. Our findings provide meaningful evidence particularly as it relates to the correlation of Enterococci with pathogens and other non-microbial parameters. It also provides empirical data to validate the applicability of the enterococci indicator paradigm for bacteriological beach quality monitoring in Malaysia. The current study thus provides policy decision makers evidenced based approach to parameter streamlining for optimized beach sampling and sustainable bacteriological quality monitoring.
\end{abstract}

Keywords: Enterococci; Indicator; Recreational beaches; Bacteriological quality monitoring; Multivariate approach; Malaysia

\section{Background}

In Western nations, beach water and sand quality monitoring has attracted significant attention in recent years owing to improved legislation (Casas et al., 2011). This development partly may be due to the availability of institutional frameworks-scientific, managerial and engineering

\footnotetext{
*Correspondence: asmat@ukm.my; ayokunled@yahoo.com

'School of Biosciences and Biotechnology, Faculty of Science \& Technology, Universiti Kebangsaan Malaysia, 43600, UKM Bangi, Malaysia

${ }^{2}$ Institute of Ecology and Environmental Studies, Obafemi Awlowo University, Ile-Ife, Nigeria

Full list of author information is available at the end of the article
}

competencies, considerable budgetary allocations and relevant political and stakeholder willpower that concertedly work to ensure the functionality of robust surveillance systems. Yet in these countries, there have been accounts reported of alarming levels of bacteria found in faeces and dangerous heavy metals in contaminated storm water flowing into beaches (Oshiro and Fujioka, 1995; Olapade et al., 2006; Grant et al., 2001; Novais et al., 2005; Yoder et al., 2004; Debacker et al., 2000). This often results in a number of public health advisories and beach closures (Graham et al., 2009; Casas et al., 2011). Furthermore, epidemiological research on the effects on health of

\section{实 Springer}


swimming at bathing beaches has shown that swimming in bathing beaches carries some risk of illness even when these beaches comply with existing legislative standards (Barrell et al. 2000).

The situation may be particularly worrisome in less economically developed countries where legislative standards do not exist as a result of frail institutions and tight budgets. In such cases, a prevailing absence of surveillance schemes may allow in beaches undetected pollution from stormwater, domestic sewage and industrial effluents (Kuylenstierna et al., 2009). The situation is exacerbated as less developed nations are often at a loss on how to develop workable standards for the purpose of beach water quality monitoring (Johnstone, 2007). Reimann and David Banks (2004) also highlighted the problems of setting meaningful action levels or maximum admissible concentrations (MAC-values) for water quality. Usually, public authorities and responsible politicians consider water quality statistics and take a decision on what proportion of failures they think can be accepted based on a consideration of political factors, economic factors and suggested MAC hinged on available empirical data. In cases where there are no indigenous studies that present empirical findings which suggest epidemiologically proven action levels or maximum admissible concentrations that make a case for the initiation of a beach water bacteriological quality monitoring (BQM) program, a worst case scenario of political inaction and negligence may become observable (Dada et al., 2012).

Although, with a more or less generalist approach, a surveillance program is currently in place for marine water quality (DOE, 2006) that lays emphasis on levels of E.coli, oil and grease, total suspended solids and selected heavy metals. Public recreational beaches are however, apparently left out of these surveillance schemes. A recent report highlighted challenges in the management of coastal recreational beaches in Malaysia (Dada et al., 2012). Particularly worrying is the possibility of direct sewage and stormwater discharge into beaches coupled with the apparent absence of early warning systems that inform the public on how safe the beaches are. Also recent review articles on recreational beaches in Malaysia have highlighted potential impacts of tourism activities, shipping, refinery effluent, land reclamation and coastal zone property development on recreational water quality (Dada et al., 2012; Praveena et al., 2011). Every year, an estimated 120 million cases of gastrointestinal illnesses and 50 million cases of respiratory ailments are contracted by bathers in polluted coastal waters (Shuval, 2003). It could thus be posited from a public health point of view, that there is the need for the development of a specific bathing beach water bacteriological quality monitoring (BQM) scheme in Malaysia.

Agreeably, these bathing beach bacteriological quality monitoring schemes will be built on data generated from for a dependable information collection system capturing output from indigenous studies with carefully planned experimental designs that aim to support early warning systems, trigger public behavioural change and the political will power needed for high-level policy decision making. The challenge at hand is thus no longer that of generating or accumulating beach water quality data but one of integrating information in a systematic manner for the purpose of making decisive policy judgements on beach water quality management (Dada et al., 2012). Given the intricacies associated with study design, methodology, data collation and interpretation in water quality monitoring schemes (Ongley, 1997), it is imperative that a robust approach be adopted for interpretation of generated data so that the original purpose is not defeated.

One of such approaches is the use of multivariate analysis for data extrapolation. A number of multivariate statistical techniques, such as cluster analysis (CA), principal component analysis (PCA), factor analysis (FA) and discriminant analysis (DA) offer significant assistance in the interpretation of complex data matrices. The outcome is thus a generally improved understanding of the water quality and ecological status of the studied systems. The application of multivariate statistical techniques also enhances the identification of possible factors that influence water systems. These undoubtedly offer a valuable tool for reliable and sustainable management of water resources (Lee et al., 2001; Adams et al., 2001; Alberto et al., 2001; Reghunath et al., 2002; Simeonov et al., 2003, 2004). Previously published literature indicate that multivariate statistical techniques have successfully assisted in characterizing surface and freshwater quality (Helena et al., 2000; Singh et al., 2004, 2005). For example, multivariate statistical methods in a regional study that predicted nonpoint heavy metals sources in soil (Facchinelli et al., 2001). Multivariate approach also helped in interpreting a large chunk of complex data matrix produced after an evaluation of several surface water parameters in Northern Greece (Simeonov et al., 2003). Another principal application of multivariate statistical analysis particularly for the identification of contributory pollutant sources was explored in another study by Terrado et al. (2006). Sherestha and Kazama (2007) also adopted CA, PCA, PFA, and discriminant analysis as multivariate techniques in the evaluation of temporal and spatial variations of a large complex water quality data set generated from their study on the Fuji River basin.

Going beyond mere making a case for the birth of a specific BQM scheme in the Malaysian context, there is the need to evaluate various water quality parameters for appropriateness and inclusion in the envisioned BQM scheme. This will reduce labour and ensure that 
money is not wasted on inappropriate or redundant parameters. To evaluate beach water quality, various microbial groups have been used as indictors of contamination. These include the E. coli, Enterococcus (USEPA 2004; Sinigalliano et al., 2010), C. perfringens (Wiedenmann et al., 2006; Miller et al., 2010), and Staphylococcus aureus (Abdelzaher et al., 2010). As this group of indicator organisms was selected based on epidemiological studies carried out mostly in temperate waters of the developed world (WHO, 2003), it has been questioned whether these could be applicable to resort beaches in tropical or subtropical climates (Curiel-Ayala et al. 2012). Tenets of this school of thought have thus proposed the introduction of other indicator organisms for the evaluation of recreational waters, in the conditions which obtain in subtropical settings (Salas and Robinson, 2006) with typical day temperature ranging from $24^{\circ} \mathrm{C}$ to $29^{\circ} \mathrm{C}$. In hotter tropical climates like Malaysia, where temperatures could reach as high as $35^{\circ} \mathrm{C}$, the situation may apparently not be the same bearing in mind the effect of temperature on microbial growth dynamics. Arriving at a choice parameter for beach water quality monitoring may thus warrant the need for indigenous studies that comparatively present assessments of these microorganisms used as indictors of beach water pollution.

To enhance the birth of a cost-effective, efficient BQM scheme for the ultimate goal of sustainable beach management and public health protection in Malaysia, the current study thus aims at providing empirical findings that validate an appropriate water quality parameter for adoption in BQM. This is the first study that assesses the validity of enterococci as an ideal indicator for BQM in Malaysia using a multivariate approach. Partly, we aimed at generating spatial data related to quality of these beaches. Secondly, we aimed at generating correlations between Enterococci and other indicator organisms, between Enterococci and other water quality parameters used in water quality monitoring. Our third objective was to explore the use of multivariate techniques in validating an Enterococci-based indicator organism paradigm applicable for beach water bacteriological quality monitoring in Malaysia.

\section{Results and discussion}

\section{Physicochemical parameters}

The physicochemical parameters in seawater and sediments collected from all location were determined and presented in Table 1 . The temperature of all water samples tested ranged from 26.6 to $29.56 \pm 0.8^{\circ} \mathrm{C}$. Conductivity ranged between 0.08 and $28.70 \pm 0.05$ and dissolved oxygen between $1.99 \pm 0.18$ and $7.60 \pm 0.12$. Recorded $\mathrm{pH}$ values (7.00-8.36) differed depending on the sample location.

\section{Population density and patterns}

All values of population counts were $\log$ transformed prior to statistical analysis. Geometric means were thus recorded after the analysis as mean log values \pm standard deviation. The mean total plate count observed for all studied beach water samples ranged from $6.01 \pm 0.02 \mathrm{log}$ $\mathrm{CFU} / 100 \mathrm{ml}$ to $9.89 \pm 0.01 \log \mathrm{CFU} / 100 \mathrm{ml}$. The highest and lowest counts were observed for samples collected from Tok Bali 1B (9.89 $\log C F U / 100 \mathrm{ml})$ followed closely by Paintai Irama (9.86 $\log \mathrm{CFU} / 100 \mathrm{ml})$, Kuala Besar 1B (9.73 $\log \mathrm{CFU} / 100 \mathrm{ml}$ ) and Pantai Sabak (9.68 logCFU/ $100 \mathrm{ml}$ ). Pantai Sri Tujuh 1A \& 1B, PCB1A and Pantai Senuk $1 \mathrm{~B}$ ranked lowest in the mean log aerobic bacteria counts $(6.01 \pm 0.02 \mathrm{CFU} / 100 \mathrm{ml})$. For the beach sand samples, generally higher counts were observed, with the mean $\log$ aerobic counts ranging from $10.23 \pm 0.00$ to $13.53 \pm 0.02 \mathrm{CFU} / 100 \mathrm{ml}$. The lowest mean log counts of aerobic bacteria observed for sand samples was observed for beach sediment collected from Sri Tujuh $2 \mathrm{~B}$ $(10.22 \pm 0.01)$ and PCB 1B beaches $(10.25 \pm 0.01)$.

For Enterococci counts in beach water samples, mean $\log$ counts ranged from 0 to $2.55 \pm 0.06 \mathrm{CFU} / 100 \mathrm{ml}$. Notably, Enterococci was not detected in samples from two beaches, Pantai Irama IA and Pantai Irama IB. Apart from these two beaches, Enterococci counts were comparatively lowest in Paintai Sri Tujuh 1A and Paintai Sri Tujuh 1B water samples. Analysis of recorded mean log counts for Enterococci in beach sand samples revealed more beaches with no detection of Enterococci as compared with water samples as Paintai Sri Tujuh $1 \mathrm{~A}, \mathrm{PCB}$ 1A, Tok Bali 1A, Tok Bali 1B, Kualar Bbesar 1B, Paintai Irama $1 \mathrm{~A}$ and $1 \mathrm{~B}$ all yielded negative results during the enumeration of Enterococci in the collected beach sediments. Higher mean log counts however were observed for sand samples collected from Paintai Sri Tujuh 3 beach $(1.31 \pm 0.01 \log C F U / 100 \mathrm{ml})$. In a few instances, higher Enterococci counts in beach water was recorded than in beach sand particularly for Pantai Sri Tujuh 1B and Pantai Sri Tujuh 3. Notably, most beach sand samples commonly harboured fewer Enterococci than the beach water samples. This difference however was not statistically significant as $\mathrm{p}$ was found greater than 0.99 for the mean $\log \mathrm{CFU} / 100 \mathrm{ml}$ comparisons. Currently, there is no enforceable standard available in Malaysia for designated bathing beaches to comply with. Also no enterococci standards exist in Malaysia for the purpose of comparison. Comparing enterococci levels in this study with the tabulated benchmark documented for bathing waters in Barrell et al. (2000) in concert with the Bathing Waters Regulation (1991), counts obtained in this study was in one of the beaches up to two-fold higher than the recommended guide levels. Usually the risk to health increases in proportion to the amount of faecal pollution as measured by indicator organisms. 
Table 1 Physico-chemical parameters

\begin{tabular}{|c|c|c|c|c|c|}
\hline Beach & $\mathrm{T}(\mathrm{W})$ & $D(W)$ & $S(W)$ & $\mathrm{DO}(\mathrm{W})$ & $\mathrm{pH}(\mathrm{W})$ \\
\hline SRI $71 \mathrm{~A}$ & $28.23 \pm 0.01$ & $26.74 \pm 2.82$ & $16.85 \pm 0.92$ & $7.10 \pm 0.10$ & $8.14 \pm 0.03$ \\
\hline SRI 7 1B & $28.85 \pm 0.01$ & $2.75 \pm 0.00$ & $1.41 \pm 0.00$ & $5.94 \pm 0.02$ & $7.88 \pm 0.02$ \\
\hline SRI 72A & $28.47 \pm 0.01$ & $27.30 \pm 0.20$ & $17.02 \pm 0.13$ & $6.96 \pm 0.24$ & $8.24 \pm 0.01$ \\
\hline SRI 73 & $28.15 \pm 0.00$ & $1.96 \pm 0.03$ & $0.99 \pm 0.02$ & $1.99 \pm 0.18$ & $7.44 \pm 0.05$ \\
\hline PCB $1 \mathrm{~A}$ & $28.23 \pm 0.04$ & $24.22 \pm 3.63$ & $12.52 \pm 0.46$ & $7.60 \pm 0.12$ & $8.24 \pm 0.02$ \\
\hline PCB 1B & $28.28 \pm 0.01$ & $26.82 \pm 1.14$ & $17.73 \pm 0.00$ & $7.51 \pm 0.08$ & $8.23 \pm 0.00$ \\
\hline TOK BALI 1A & $29.20 \pm 0.01$ & $3.32 \pm 0.01$ & $1.73 \pm 0.01$ & $4.52 \pm 0.06$ & $7.00 \pm 0.03$ \\
\hline TOK BALI 1B & $29.05 \pm 0.01$ & $22.85 \pm 0.43$ & $13.91 \pm 0.12$ & $7.56 \pm 0.03$ & $7.84 \pm 0.04$ \\
\hline KUALA BESAR 1A & $26.60 \pm 0.00$ & $0.17 \pm 0.00$ & $0.08 \pm 0.00$ & $2.02 \pm 0.27$ & $6.80 \pm 0.01$ \\
\hline KUALA BESAR 1B & $27.15 \pm 0.04$ & $17.39 \pm 1.67$ & $8.98 \pm 0.46$ & $7.81 \pm 0.02$ & $7.95 \pm 0.06$ \\
\hline PANTAI SENUK $1 \mathrm{~A}$ & $28.63 \pm 0.03$ & $26.48 \pm 0.50$ & $18.20 \pm 0.02$ & $7.15 \pm 0.02$ & $8.31 \pm 0.00$ \\
\hline PANTAI SENUK 1B & $28.45 \pm 0.01$ & $1.77 \pm 0.03$ & $0.89 \pm 0.01$ & $3.92 \pm 0.08$ & $7.54 \pm 0.01$ \\
\hline PAITAI IRAMA 1A & $28.78 \pm 0.66$ & $44.70 \pm 0.44$ & $28.70 \pm 0.05$ & $6.91 \pm 0.06$ & $8.30 \pm 0.01$ \\
\hline PANTAI IRAMA 1B & $29.56 \pm 0.08$ & $42.88 \pm 1.10$ & $27.66 \pm 0.65$ & $6.92 \pm 0.06$ & $8.34 \pm 0.01$ \\
\hline PANTAI SABAH & $28.66 \pm 0.01$ & $34.03 \pm 0.15$ & $20.21 \pm 0.94$ & $7.36 \pm 0.17$ & $8.37 \pm 0.01$ \\
\hline
\end{tabular}

Using a baseline approach for all sampled beaches involving the direct use of a detection limit of one colony forming unit per $100 \mu \mathrm{l}$ aliquot of water samples, only four beaches were found to contain elevated levels of Salmonella typhi to be detectable at this limit with mean log counts ranging from a transformed value of $3.03 \pm 0.46 \mathrm{cfu} / 100 \mathrm{ml}$ to $4.70 \pm 0.01 \mathrm{CFU} / 100 \mathrm{ml}$. Vibrio cholerae was not detectable in six out of the sixteen beach locations considered in this study. In beach water samples where it was detected, it was detected at a mean log count range of $3.00 \pm 0.00$ to $6.33 \pm 1.15$ $\mathrm{cfu} / 100 \mathrm{ml}$. For beach sand analysis, while most sediment samples contained fewer levels of Vibrio cholera than their water sample counterparts, counts obtained for Vibrio ranged from $3.30 \pm 0.01$ to $6.90 \pm 1.53$ $\log \mathrm{CFU} / 100 \mathrm{ml}$. Counts were recorded for other noncholerae Vibrio species in both beach water ad sediment samples. For beach water samples, apart from samples collected from Pantai Sri Tujuh 1B, 2A, 3 and Kuala Besar 1B, tested water samples were found negative. Positive samples for Vibrio spp. were found to have counts that ranged from $3.48 \pm 0.01 \log C F U / 100 \mathrm{ml}$ (Sri 72B) to $6.33 \pm 1.53 \log \mathrm{CFU} / 100 \mathrm{ml}(\mathrm{PCB} 1 \mathrm{~B})$. Of all the sand samples analysed, only six sampled beaches were found positive to Vibro species with a mean $\log$ counts of $3.301 \pm 0.01$ CFU/100 ml (Pantai Irama1A, Pantai Sri Tujuh 2B), $4.18 \pm$ $0.01 \mathrm{CFU} / 100 \mathrm{ml}$ (Pantai Senuk), $4.43 \pm 0.98 \mathrm{CFU} / 100 \mathrm{ml}$ (Pantai Sri Tujuh 2A), $6.05 \pm 1.65$ CFU/100 ml (Pantai Sri Tujuh 3) and $6.43 \pm 1.47 \mathrm{CFU} / 100 \mathrm{ml}$ (Pantai Senuk).

Values obtained for mean log of total coliform counts for beach water samples ranged from $3.0 \pm 0.01 \mathrm{CFU} /$ $100 \mathrm{ml}$ (PCB1A) to $6.67 \pm 1.68 \mathrm{CFU} / 100 \mathrm{ml}$ (Kuala Besar
1A). Total coliform counts for water samples were numerically higher among beach sand samples although the difference was found not to be statistically significant as $\mathrm{p}$ value obtained from the analysis of variance of means was greater than 0.99 . Faecal coliforms were only detectable at Kuala Besar 1B beach water samples but not in the beach sand samples. Similarly only in two beaches (Pantai Sri Tujuh 3 and Tok Bali 1A) were faecal coliforms detected with mean log counts higher than 4.0 per $100 \mathrm{ml}$ of seawater sample. Faecal coliforms are regarded as more specific indicators of faecal contamination than total coliforms. It is interesting to note that comparing data obtained in this study with the Bathing Waters Regulation (1991), a guide and imperative level of $100 \mathrm{cfu} / 100 \mathrm{ml}$ and $2000 / 100 \mathrm{ml}$ (equivalent to $1.0 \log \mathrm{cfu} / \mathrm{ml}$ and $3.30 \log \mathrm{cfu} / \mathrm{ml}$ respectively), faecal coliform counts considerably complied with this standard. Only one of the beaches failed to comply and unlike the case of enterococci which appeared to be more sensitive capturing another two beaches that failed to comply to the stipulated standards. Our observation is in concert with studies that have shown that the bacterial indicator most strongly associated with risk to health seems to be the enterococci count (WHO, 2003; Fleisher et al., 1993).

\section{Pictorial relationships between Enterococci and other parameters measured in the study}

Patterns observed in the readings of physico-chemical parameters and concentrations of microbial parametars were observed using three dimensional surface plots that show pictorial inter-relationships between the tested parameters. The parameters used in the plots are (1) 
TPCS-total heterotrophic plate count of beach sediment samples (2) EW-Enterococci concentration in seawater (3) ES- Enterococci concentration in beach sediment samples (4) SW- Salmonella typhi concentration in beach water samples (5) SAW-Staphylococcus aureus concentration in beach water samples (6) VCW-Vibro cholerae concentration in beach water samples (7) VCSVibrio cholerae concentration in beach sediment samples (8) VSW-Vibrio spp. concentration in beach water samples (9) VSS - Vibrio species concentration in beach sediment samples (10) TCW - Total coliform count of beach water samples (11) TCS- Total coliform count of beach sediment samples (12) FCW - Faecal coliform count of beach water samples (13) FCS- Faecal coliform count of beach sand samples (14) AW- Aeromonas hydrophila concentration in beach water samples (15) EW-Enterococci concentration in beach water samples (16) SAS- Staphylococcus aureus counts of beach sediment samples (17) $\mathrm{T}$ - Beach water temperature in ${ }^{\circ} \mathrm{C}$ (18) D - Dissolved oxygen in \% air saturation (19) DO Dissolved oxygen in mg/L (20) $\mathrm{pH}$ - measure of the activity of the hydrogen ion concentration of beach water sample (21) S- Salinity (in ppt). Variables (1) - (16) were recorded in $\log C F U / 100 \mathrm{ml}$. Data was pooled from all the beaches for the analyses.

Two major sets of patterns are presented (i) the ones showing how other parameters (microbial and nonmicrobial) vary with each other (Figure 1f - 1m) (ii) patterns showing how Enterococci varies with other parameters (Figure 1a - 32). From the surface plots generated, increasing concentrations of total coliform in beach water samples corresponded with increasing concentrations of Enterococci. A similar observation was observed between the concentrations of Enterococci and Staphylococcus aureus in water (2a). Enterococci concentration remained fairly constant at temperatures between $26-28^{\circ} \mathrm{C}$ but gradually declined at temperatures above $28^{\circ} \mathrm{C}$ (2b). Enterococci concentration in seawater gradually increased with increasing salinity levels but began a steady decline at salinity levels above 15 ppt (2c). Enterococci concentration in seawater generally reduced with increasing $\mathrm{pH}$ values above neutral (2d). However, the case for Enterococci concentration in beach sand was somewhat different as concentration of Enterococci reduced as $\mathrm{pH}$ levels dropped below 7 and picked up at neutral ph value before gradually declining as $\mathrm{pH}$ advanced into more alkaline values (2e). Generally, Salmonella typhi count in water (SW) tended to decrease with increasing DO (2f). At increasing $\mathrm{pH}$ values however, SW decreased with increasing D value (2g). Again, Salmonella typhi count in water tends to decrease with increasing salinity (S) (2h). Total plate count of bacteria in seawater generally increased with increasing salinity (S) (2i). Staphylococcus aureus concentration in sand reduced with increasing concentration of Vibro species in seawater albeit in a fluctuating manner (2j). Vibrio cholerae concentration in seawater generally reduced with increasing levels of TCS (3k) and FCW (2m) and with reducing levels of Vibrio species (2n) while Vibro cholerae concentration in beach sand reduced with reducing levels of Vibrio species in beach sand (2l). Generally, dissolved oxygen concentration increased with increasing $\mathrm{pH}(2 \mathrm{~m})$.

It should however be noted that these pictorial representation from the data obtained are just raw presentations of how the parameters vary with one another. In statistical terms, a more reliable approach is to use correlation analysis that presents information on how each parameter correlates with the others. The major consideration besides the correlation ranking here is the significance levels. Using a Pearson correlation analysis, it was observed that Enterococci concentrations significantly correlated to more number of parameters than any other microbial or nonmicrobial parameter analyzed in this study (additional data). Both seawater and sand concentrations of Enterococci correlated in varying strengths to the concentration of Salmonella typhi in water $(\mathrm{r}=0.445, \mathrm{p}=0.002$ and $\mathrm{r}=$ $0.739, \mathrm{p}=0.000$ respectively). The correlation between $E n-$ terococci concentration in sand and the concentration of pathogens in seawater as was observed in our study supports the position of other studies that suggested beach sand can be a source of faecal indicator bacteria and pathogens to adjacent waters (Oshiro \& Fujioka, 1995; Oliveira \& Mendes, 1992).

The correlation of Enterococci in seawater however was inversely correlated to temperature $(\mathrm{r}=-0.590, \mathrm{p}=$ $0.000)$, salinity $(\mathrm{r}=-0.386, \mathrm{p}=0.009)$ and dissolved oxygen $(\mathrm{r}=-0.537, \mathrm{p}=0.000)$. The negative correlation of water temperature to Enterococci antogonised the concerns that indicator organisms may grow in the environments as argued by previous studies (Beversdorf et al., 2007; Shah et al., 2011; Phillips et al., 2011 and Goodwin et al., 2012). It may be that the organism is not significantly viable at this temperature taking into account the prevailing $\mathrm{pH}$, salinity, oxygen content and other physicochemical parameters of the beach water samples tested in our study. Hopefully studies will emerge in the future that substantiate this observation while specifically exploring the survival potential of Enterococci in bathing beach water and beach sand in the tropical context available in Malaysia. In our study, Enterococci concentration in beach sand correlated inversely but in stronger terms with dissolved oxygen levels in seawater. Apart from the weak correlation of Staphylococcus aureus concentration in seawater with Vibro species $(r=0.302$, $\mathrm{p}=0.037)$ and total coliforms $(\mathrm{r}=0.392, \mathrm{p}=0.006)$ in seawater, no other correlations existed between Staphylococcus concentration and other parameters. Similarly, concentration of Staphylococcus aureus in beach sand correlated 


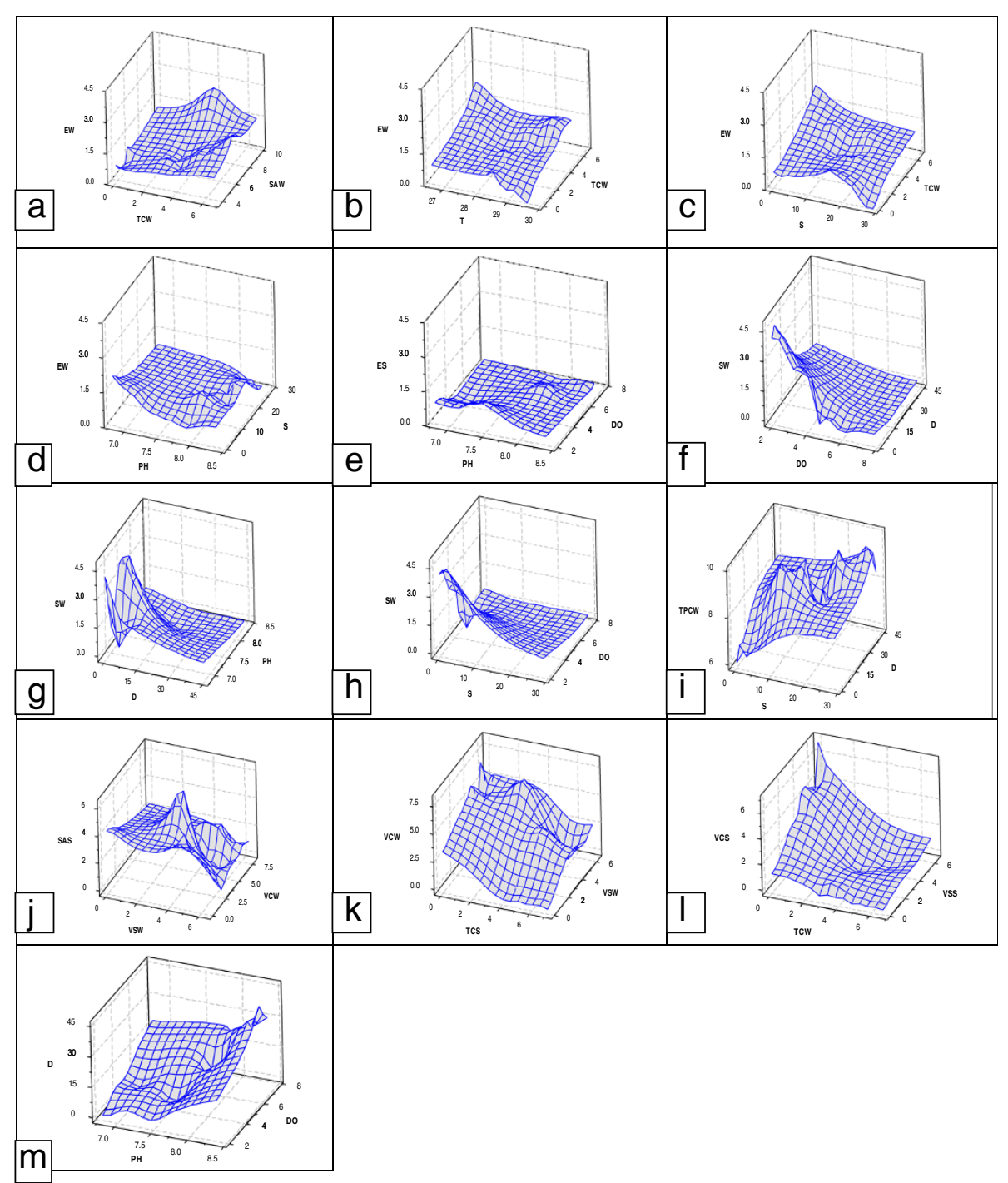

Figure 1 Three dimensional surface plots depicting pictorial representation of relationships between selected parameters, a-m being plots of EW/TCW/SAW, EW/T/TCW, EW/S/TCW, EW/pH/S, ES/pH/DO, SW/DO/D, SW//D/pH, SW/S/DO, TCPS/S/D, SAS/VSW/VCW, VCW/ TCS/VSW, VCS/TCW/VSS and D/pH/DO respectively. (1) TPCS-total heterotrophic plate count of beach sediment samples (2) EW- Enterococci concentration in seawater (3) ES- Enterococci concentration in beach sediment samples (4) SW- Salmonella typhi concentration in beach water samples (5) SAW-Staphylococcus aureus concentration in beach water samples (6) VCW-Vibro cholerae concentration in beach water samples (7) VCS- Vibrio cholerae concentration in beach sediment samples (8) VSW-Vibrio spp. concentration in beach water samples (9) VSS - Vibrio species concentration in beach sediment samples (10) TCW - Total coliform count of beach water samples (11) TCS- Total coliform count of beach sediment samples (12) FCW - Faecal coliform count of beach water samples (13) FCS- Faecal coliform count of beach sand samples (14) EW- Enterococci concentration in beach water samples (15) T- Beach water temperature in ${ }^{\circ} \mathrm{C}(16) \mathrm{DO}$ - Dissolved oxygen in mg/L (17) pHmeasure of the activity of the hydrogen ion concentration of beach water sample (18) S- Salinity (in ppt).

weakly with those of Vibro species $(\mathrm{r}=0.360, \mathrm{p}=0.012)$ and total coliforms $(\mathrm{r}=0.595, \mathrm{p}=0.000)$ in beach sand. This observation questions the adoptability of $S$. aureus for use as beach water quality indicator in the considered location. Our findings however contradict recent comparative study by Goodwin et al. (2012) that showed strong correlations in seawater and sand between water temperature and seawater concentration of Enterococci. The reason for this might be because the study was conducted in possibly temperate bathing waters in the United States. Our study was conducted in a tropical setting with typically high day temperature reaching up to $33^{\circ} \mathrm{C}$. This might have significant implications on population dynamics of the microorganisms studied. Notwithstanding, our findings are in concert with others that reported that $S$. aureus do not correlate with various other indicators (El-Shenawy, 2005; Calderon et al. 1991; Selvakumar and Borst, 2006; Yamahara et al., 2012; Enns et al., 2012). 
Notably, faecal coliform concentration in seawater did not correlate with any of the parameters tested apart for inverse correlations with Vibro cholerae $(\mathrm{r}=-0.436, \mathrm{p}=$ 0.02 ) in seawater. This observation presents a shadow of doubt on the appropriateness of faecal coliform concentration for seawater quality monitoring in the studied location. Interestingly also, faecal coliform concentration in sand also did not correlate with any of the tested beach sand quality parameters. On a general note, the results of the correlation analysis apparently indicate that Enterococci concentrations seem to be a preferred choice indicator bearing in mind that it correlated more and better with other microbial parameters. This observation is in concert with previous studies (WHO, 2003; Fleisher et al., 1993).

\section{Regression analysis}

Statistical Relationships between enterococci, other microbial and non-microbial parameters were explored using a combination of simple and multiple linear regression analysis. First, enterococci count (in logcfu/ml) was compared with other microbial indicators tested for water and sand respectively. Again enterococci counts of water samples were compared with varying combinations of the other parameters analyzed in this study. The results of regression analysis are presented in Table 2. Each of the parameters were found to have a extremely significant relationship with Enterococci count $(\mathrm{p}<$ 0.0001). A number of studies have employed multivariate linear or non-linear approaches for studying relationships between varying environmental parameters. Regardless of the model, $\mathrm{r}^{2}$ value is generally accepted as a standard criterion for the predictive success of models (Håkanson et al., 2003). However, it should be noted that in some instances, a univariate simple regression model could yield high $\mathrm{r}^{2}$ values but may fail to define the complex relationship between water quality parameters. This has prompted for the need to employ multivariate techniques. Nonetheless, determination coefficient $\left(\mathrm{r}^{2}\right)$ remains a popular tool in environmental modeling. To ensure that inherent errors associated with this approach was not the case for the model generated, the model validity was evaluated as described by MINITAB using error terms (or residuals) that have a mean of zero and constant variance. To check these assumptions, residuals versus fitted values plot and normality probability plots of the residuals were generated (Figure 2) and checked for constant variance while confirming that the residuals are scattered randomly around zero. The simple regression model generated in this study was able to predict with a maximum predictive success of $69.64 \%$ using just a combination of 5 parameters. The model used to predict Entercocci counts in water samples is given as:

$$
\begin{aligned}
\mathrm{EW}= & 16.5116+0.199223 \mathrm{TPCS}+0.129839 \mathrm{SAW} \\
& -0.0589192 \mathrm{VCW}-0.0893019 \mathrm{AW} \\
& +1.89376 \mathrm{DO}(\mathrm{W})-21.8692 \mathrm{pH}(\mathrm{W})
\end{aligned}
$$

Where EW is the beach water concentration of Enterococci in logCFU/100 mL, TPCS is the total heterotrophic plate count (in $\log \mathrm{CFU} / 100 \mathrm{~mL}$ ) of soil samples collected beneath the surfing zone where water samples were collected, SAW is Staphylococcus aureus concentration of beach water samples (in $\log \mathrm{CFU} / 100 \mathrm{~mL}$ ), VCW is Vibrio cholerae concentration of beach water sample (in logCFU/ $100 \mathrm{~mL}$ ), AW is the Aeromonas hydrophila concentration (in $\log \mathrm{CFU} / 100 \mathrm{~mL}$ ), DO is dissolved oxygen in water (in $\mathrm{mg} / \mathrm{L})$ and $\mathrm{pH}(\mathrm{W})$ being the $\mathrm{pH}$ value of beach water sample. It was interesting to note that our analysis produced a model which could factor in S. aureus concentration in its prediction of enterococci concentrations in seawater. Goodwin et al. (2012) also arrived at a best-fit model that related $S$. aureus in seawater with enterococci levels. The predictive model that could predict en-

\begin{tabular}{|c|c|c|c|c|c|}
\hline Included independent variables & Regression coefficient (bk) & Standard error of bk & $\mathbf{T}$ & $\mathbf{P}$ & $R^{2}(\%)$ \\
\hline Constant & 16.5116 & 2.65543 & 6.21805 & $0.000^{*}$ & 69.64 \\
\hline TPCS & 0.1992 & 0.06151 & 3.23898 & $0.002^{*}$ & \\
\hline SAW & 0.1298 & 0.03961 & 3.27766 & $0.002^{*}$ & \\
\hline VCW & -0.0589 & 0.01755 & -3.35683 & $0.002^{*}$ & \\
\hline AW & -0.0893 & 0.02165 & -4.12448 & $0.000^{*}$ & \\
\hline DO & 1.8938 & 0.55339 & 3.4221 & $0.002^{*}$ & \\
\hline $\mathrm{pH}$ & -21.8692 & 3.48283 & -6.27915 & $0.000^{*}$ & \\
\hline
\end{tabular}
terococci levels in beach water based on Staphylococcus

Table 2 AVOVA results of regression analysis $(n=48)$

${ }^{*} \mathrm{p}<0.01$, TPCS-total heterotrophic plate count of beach sediment samples, SAW-Staphylococcus aureus concentration in beach water samples, VCW-Vibro cholerae concentration in beach water samples, VCS- Vibrio cholerae concentration in beach sediment samples, AW- Aeromonas hydrophila concentration in beach water samples, EW- Enterococci concentration in beach water samples, DO - Dissolved oxygen in mg/L (20) pH- measure of the activity of the hydrogen ion concentration of beach water sample. 

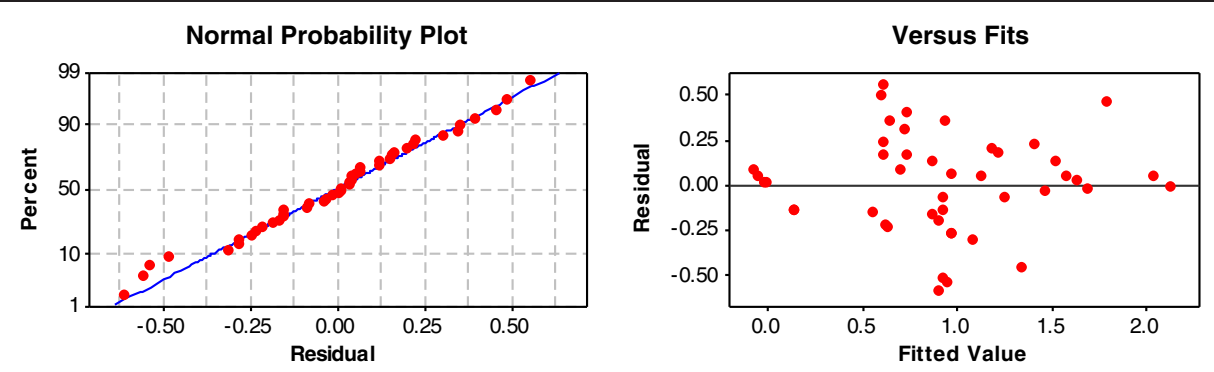

Figure 2 Residual plots for generated Enterococci model validation.

aureus counts alone in water, although significant, had a low predictive power of $27.03 \%$. Notably, when SW, TCS and TCW were each added to the model, the predictive power of the generated model increased to $70.10,70.89$ and $74.52 \%$ respectively. However, these were not statistically significant we attempted a predictive model that could predict Enterococci counts based on the levels of other conventional bacterial indictors for water quality. When only either of total coliforms and faecal coliforms were incorporated, the predictive ability of the obtained model were very low, $29.20 \%$ and $40.36 \%$ respectively for the model EW $=0.612+$ $0.169 \mathrm{TC}$ and $\mathrm{EC}=0.6263-0.02704 \mathrm{FCW}+0.16771 \mathrm{TC}$.

\section{Spatial similarity, site groupings and variations in beach water quality}

Cluster analysis was applied to distinct spatial similarity between the selected sampling sites. The obtained dendogram presented in Figure 3 shows groupings of all the beach sampling sites into four statistically significant clusters. As specific information documented on these beaches particularly the potential point sources of pollution are not available, visual observation of these beaches were used as a basis for classification in a bid to compare with cluster analysis. The clusters obtained from this analysis are also in agreement with these considerations. In this study, clusters 1 to 4 correspond to increasing levels of pollution in that order. We applied an approach that fed into the data matrix used for cluster analysis separate data for each of the sampling sites per beach. This was necessary to allow a reflection of specific polluted sections of each considered beach as opposed to the use of pooled data. For instance, in a separate study on Teluk chempedak, the portion of the beach receiving direct river water discharge had higher levels of pollution as compared to another site on the same beach not receiving river water discharge.

A similar observation was noted at Teluk Kemang in a separate study where a portion of the beach in the main bathing area receiving direct storm water discharge had significantly higher loads of antibiotic resistant bacteria as compared to other bathing sites not directly receiving pollution loadings from the stormwater discharge pipes. Obviously from our clustering results, three of the beaches (Tok Bali, Sri 7 and Kualar Besar) had sampling sites grouped in more than one cluster as opposed to a situation where all sampling sites on the same beach are clustered in a group. This observation supports the dynamic nature of microbial loadings in beaches. It should thus be noted for studies that will emerge in the future, sampling spots that do not representatively cover the entire length of any beach in question may be far from presenting an accurate picture of the overall quality of the beach. It is also recommended that future strategies for $\mathrm{BQM}$ in Malaysia should include a zoning strategy for individual beaches such that each zone of a beach in question is classified based on the potential pollution input and associated level of threat or risk to public health. With this system in place, bathers are able to make an informed choice on which portion of the beach to bath. Although factors that drive bathers preference for bathing sites within a beach is albeit complex and subjective, from physical observation of beaches in Malaysia, it could be noted that bathers on arriving at a designated beach generally would make a choice on which portion of the beach to bathe based on nearness to amenities such as food stalls, relaxation tents, speed boats etc. In a previous study, the section of Teluk Kemang beach with intense recreational activity is also very close to a storm water discharge pipe. Yet there are no early warning systems to emphasize to the public, the need to avoid swimming in the vicinity of storm water drains during or a few days after rainfall events as these drains are potential sources of pollution.

Another approach that could be built based on results of clustering analysis of data obtained from BQM is beach profiling. Unlike the beach zoning previously iterated involving multiple zones per beach, beach water profiling is a general picture involving a classification system for several beaches, in which case, multiple beaches per class or zone. Beach water profiling is increasingly gaining increasing acceptance in some countries. A fundamental objective of this approach is to allow the citizenry to make an informed choice on which 


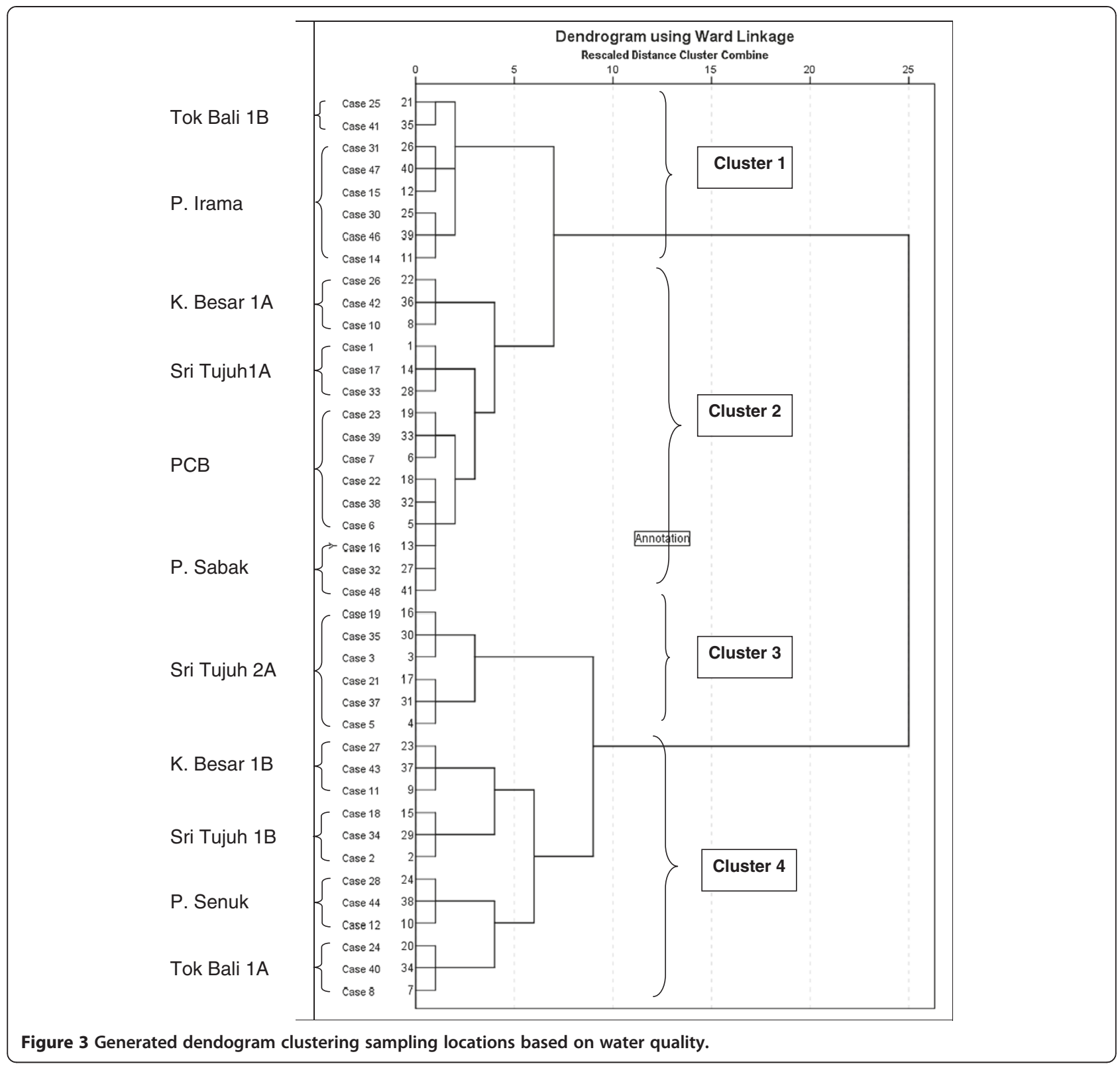

beach to choose for recreational activities. This is done via the annual public disclosure in the form of a report, the bacteriological quality of available coastal and freshwater bathing waters. Clusters built from data generated from BQM could be aligned with other factors to produce a profiling system that includes a general description of the bathing water, where wastewater outfalls and combined sewer overflows (CSOs) are positioned, potential sources of pollution, management measures, the location of the sampling points and how the beach has performed against bathing quality ratings over the previous months and years. With a beach profiling program in place, beaches could then be classified as good, fair or poor based on pre-defined quality criteria counts. It is noteworthy to assert that relevant agencies in Malaysia have made giant strides in this direction particularly for rivers in Malaysia. Water quality data from the 143 river basins throughout Malaysia are used to determine the water quality status weather in clean, slightly polluted or polluted category and to classify the rivers in Class I, II, III, IV or V based on Water Quality Index (WQI) and Interim National Water Quality Standards (INWQS) for Malaysia every year (Dada et al 2012). It is hoped that a similar classification scheme be developed for recreational beach waters. A further improvement of this approach will involve the designation of beach managers for each beach who will be responsible for putting up signs at each designated bathing waters advising on the 
beach class, current beach water quality and potential pollution sources.

\section{Compositional patters of quality and underlying factors} In our study, all 21 variables of normalized data sets for the four different spatial regions (CL1-4) in our study were used for principal component analysis (PCA). The objective of this analysis was to see the compositional patterns between the beach water samples analyzed. The second objective was to identify the factors that influence each of the patterns. The input data (variable cases) used for the PCA was a $21 \times 48$ matrix. As suggested by Helena et al. (2000), the PCA was carried out using Minitab by a diagonization of the correlation matrix. Table 3 summarizes the PCA results obtained including the loadings (participations of the original variables in the new ones) and the eigenvalues of each principal component (PC). The amount of variance presented by each PC (also shown in the table) is dependent on its eigenvalues. Several literature exist that highlight criteria involved in the classification of principal components to be retained in order to understand the underlying data structure (Jackson, 2005; Helena et al., 2000). A scree plot was used to show change in the slope after the sixth eigenvalue. In numerical terms, eigenvalues above 1 was considered as the criteria for retention as PC. Consequently, PC1-PC6 were thus retained as they had eigenvalues higher than 1 and were responsible for $86.3 \%$ of the variance or information contained in the original data set. The absolute value of the loadings is an indicator of the participation of the parameter variables in the PCs. According to Helena et al. (2000), the actual sign is a reflection of the calculation algorithm used. In Table 3, the contribution reached by each variable to the considered principal component is presented. PC1

Table 3 PCA and FA loadings generated from principal component and factor analysis

\begin{tabular}{|c|c|c|c|c|c|c|c|c|c|c|c|c|c|c|}
\hline Variable & PC1 & PC2 & PC3 & PC4 & PC5 & PC6 & & Factor1 & Factor2 & Factor3 & Factor 4 & Factor5 & Factor6 & Communality \\
\hline TPCW & -0.184 & -0.069 & -0.11 & -0.153 & -0.081 & 0.668 & & -0.371 & -0.107 & -0.085 & 0.108 & 0.077 & 0.842 & 0.882 \\
\hline TPCS & 0.224 & -0.094 & -0.255 & -0.309 & -0.245 & 0.139 & & 0.512 & 0.180 & -0.636 & -0.202 & -0.173 & 0.274 & 0.845 \\
\hline EW & 0.235 & 0.196 & 0.119 & -0.179 & -0.374 & 0.022 & & 0.429 & 0.230 & -0.027 & -0.767 & -0.123 & -0.006 & 0.841 \\
\hline ES & 0.304 & -0.063 & -0.144 & -0.074 & 0.252 & 0.067 & & 0.862 & 0.166 & -0.172 & 0.165 & -0.027 & 0.024 & 0.829 \\
\hline SW & 0.315 & 0.030 & -0.276 & -0.042 & 0.157 & 0.104 & & 0.935 & -0.081 & -0.264 & 0.019 & -0.039 & 0.074 & 0.958 \\
\hline SAW & -0.031 & 0.278 & 0.021 & 0.015 & -0.453 & -0.178 & & -0.192 & -0.270 & 0.007 & -0.707 & -0.117 & -0.179 & 0.656 \\
\hline SAS & 0.146 & -0.353 & 0.051 & 0.236 & -0.205 & -0.200 & & 0.114 & 0.459 & -0.482 & 0.114 & 0.501 & -0.367 & 0.855 \\
\hline VCW & -0.161 & 0.275 & -0.278 & 0.145 & 0.228 & -0.083 & & -0.111 & -0.832 & 0.210 & 0.133 & -0.208 & -0.034 & 0.811 \\
\hline VCS & -0.03 & -0.283 & -0.332 & -0.045 & -0.116 & -0.355 & & -0.128 & -0.048 & -0.769 & 0.352 & -0.085 & -0.234 & 0.796 \\
\hline VSW & -0.123 & 0.361 & -0.198 & 0.319 & -0.073 & -0.048 & & -0.134 & -0.868 & 0.218 & -0.283 & 0.051 & -0.111 & 0.915 \\
\hline VSS & 0.103 & -0.323 & -0.31 & -0.092 & -0.277 & 0.124 & & 0.161 & 0.164 & -0.864 & 0.131 & 0.161 & 0.220 & 0.892 \\
\hline TCW & 0.118 & 0.349 & 0.178 & 0.06 & -0.337 & 0.153 & & 0.213 & -0.088 & 0.326 & -0.835 & 0.077 & 0.036 & 0.864 \\
\hline TCS & 0.144 & -0.234 & 0.394 & -0.044 & -0.163 & -0.188 & & 0.034 & 0.846 & -0.027 & -0.127 & 0.197 & -0.311 & 0.869 \\
\hline FCW & 0.045 & -0.128 & 0.467 & -0.208 & 0.297 & 0.041 & & 0.010 & 0.771 & 0.491 & 0.197 & -0.079 & 0.004 & 0.881 \\
\hline FCS & 0.221 & -0.177 & -0.031 & 0.389 & -0.113 & 0.055 & & 0.449 & 0.149 & -0.282 & -0.004 & 0.646 & -0.196 & 0.760 \\
\hline AW & 0.035 & -0.141 & 0.171 & 0.443 & -0.058 & 0.479 & & 0.015 & 0.152 & 0.151 & 0.033 & 0.838 & 0.221 & 0.798 \\
\hline $\mathrm{T}$ & -0.196 & -0.237 & -0.022 & 0.429 & 0.01 & -0.027 & & -0.526 & -0.140 & -0.110 & 0.433 & 0.547 & -0.148 & 0.817 \\
\hline D & -0.35 & -0.124 & -0.035 & -0.051 & -0.159 & 0.032 & & -0.918 & -0.141 & -0.139 & 0.204 & -0.041 & 0.199 & 0.965 \\
\hline$S$ & -0.349 & -0.12 & -0.046 & -0.047 & -0.168 & 0.023 & & -0.917 & -0.158 & -0.154 & 0.196 & -0.043 & 0.190 & 0.966 \\
\hline DO & -0.343 & -0.032 & 0.203 & -0.099 & -0.112 & -0.018 & & -0.950 & 0.047 & 0.213 & 0.053 & -0.120 & 0.106 & 0.979 \\
\hline $\mathrm{pH}$ & -0.327 & -0.14 & -0.074 & -0.241 & 0.01 & -0.001 & & -0.795 & -0.067 & -0.141 & 0.365 & -0.300 & 0.253 & 0.943 \\
\hline Eigenvalue & 7.0098 & 3.909 & 2.7148 & 1.7736 & 1.4985 & 1.2161 & & & & & & & & \\
\hline Proportion & 0.334 & 0.186 & 0.129 & 0.084 & 0.071 & 0.058 & Variance & 6.0678 & 3.3253 & 2.7452 & 2.5779 & 1.9736 & 1.4317 & 18.1216 \\
\hline Cumulative & 0.334 & 0.52 & 0.649 & 0.734 & 0.805 & 0.863 & $\%$ Var & 0.289 & 0.158 & 0.131 & 0.123 & 0.094 & 0.068 & 0.863 \\
\hline
\end{tabular}

(1) TPCS-total heterotrophic plate count of beach sediment samples (2) EW- Enterococci concentration in seawater (3) ES- Enterococci concentration in beach sediment samples (4) SW-Salmonella typhi concentration in beach water samples (5) SAW- Staphylococcus aureus concentration in beach water samples (6) VCWVibro cholerae concentration in beach water samples (7) VCS-Vibrio cholerae concentration in beach sediment samples (8) VSW-Vibrio spp. concentration in beach water samples (9) VSS - Vibrio species concentration in beach sediment samples (10) TCW - Total coliform count of beach water samples (11) TCS- Total coliform count of beach sediment samples (12) FCW - Faecal coliform count of beach water samples (13) FCS- Faecal coliform count of beach sand samples

(14) AW- Aeromonas hydrophila concentration in beach water samples (15) EW-Enterococci concentration in beach water samples (16) SAS- Staphylococcus aureus counts of beach sediment samples (17) T- Beach water temperature in OC (18) D - Dissolved oxygen in \% air saturation (19) DO - Dissolved oxygen in mg/L (20) $\mathrm{pH}$ - measure of the activity of the hydrogen ion concentration of beach water sample (21) S- Salinity (in ppt). 
explained $33.4 \%$ of the variance and was contributed by ES, SW, D, S, DO and pH. PC2 explained $18.6 \%$ of the variance and was mainly contributed by EW, SAS, VSW, VSS, TCW. PC3 (12.9\% of the variance) was contributed by VCS, VSS, TCS and FCW. PC4 (8.4\% of the variance) is contributed by VSW, FCS, AW and T. The loadings (i.e. the contribution of each parameter towards the first and second principal components are also presented as a loading plot (Figure 4a). In the diagram, the loading of the first and second components

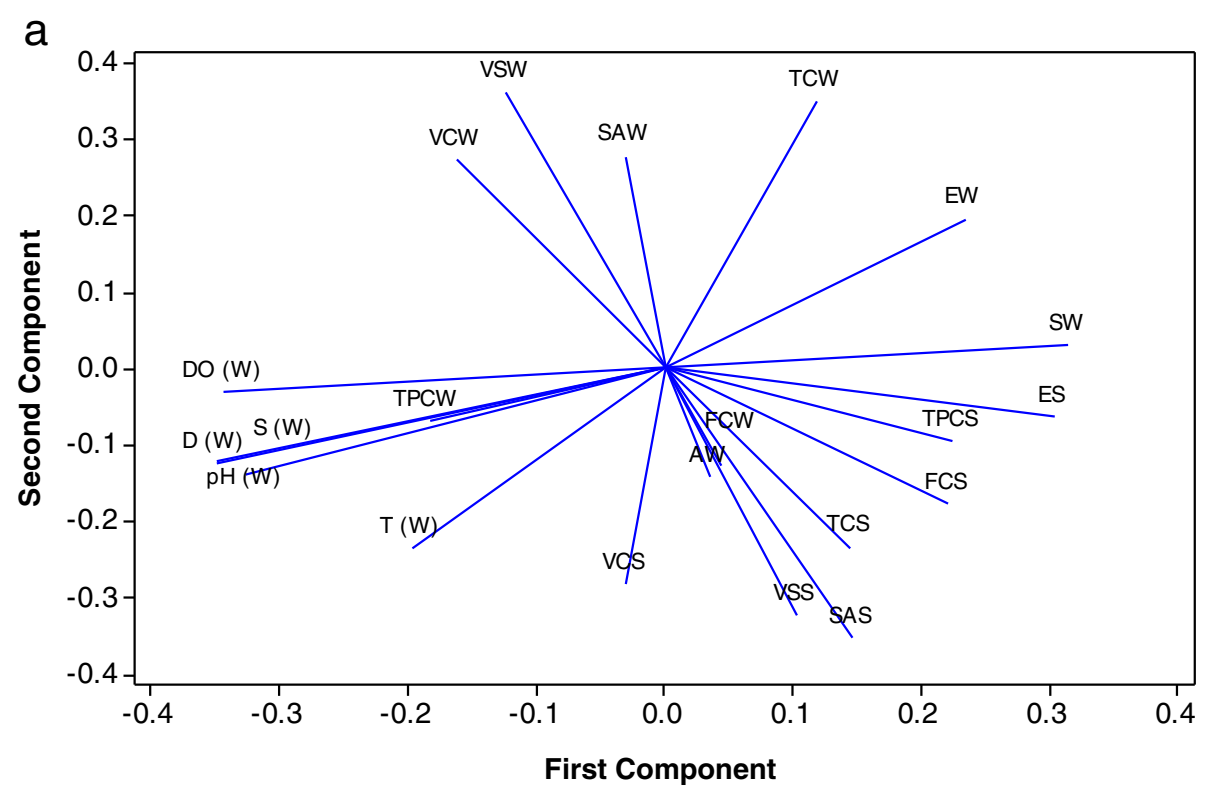

b

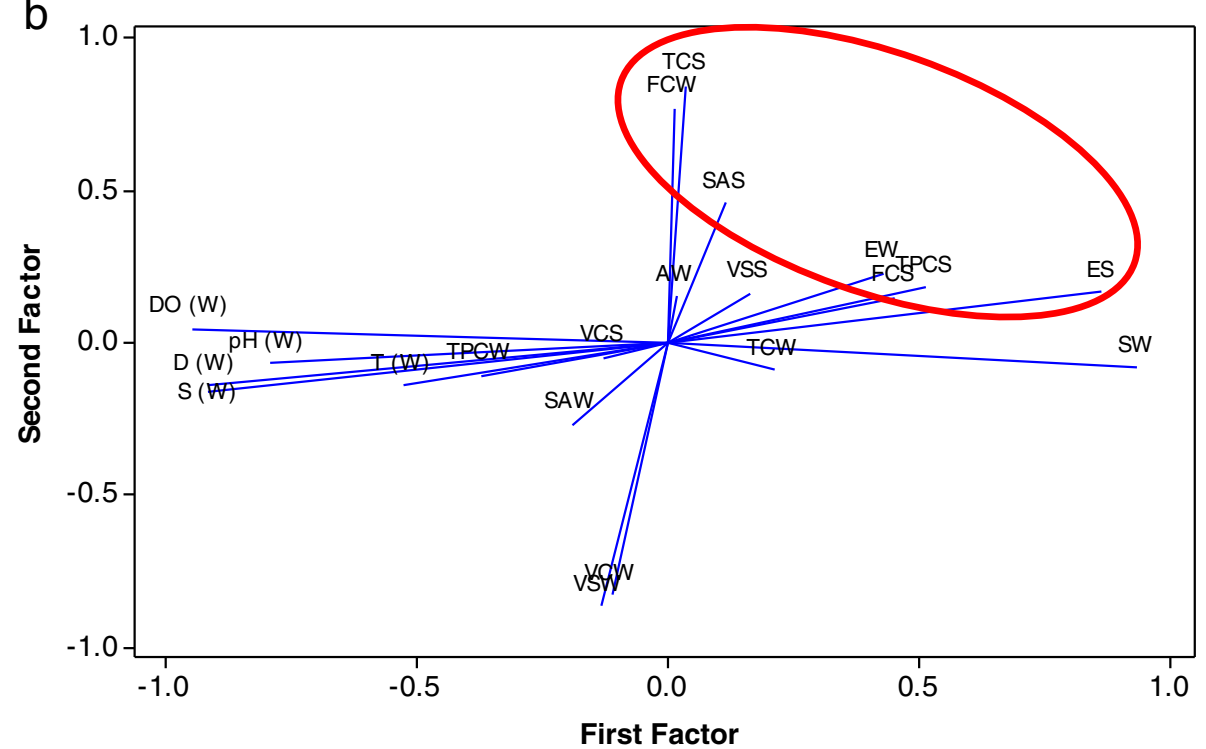

Figure 4 (a): Loading plots based on contribution of each quality parameter (a) towards the first and second component in PCA and (b) towards the first and second factor in FA (1) TPCS-total heterotrophic plate count of beach sediment samples (2) EW- Enterococci concentration in seawater (3) ES- Enterococc concentration in beach sediment samples 4) SW- Salmonella typhi concentration in beach water samples (5) SAWStaphylococcus aureus concentration in beach water samples (6) VCW-Vibro cholerae concentration in beach water samples (7) VCS- Vibrio cholerae concentration in beach sediment samples (8) VSW-Vibrio spp concentration in beach water samples 9) VSS - Vibrio species concentration in beach sediment samples (10) TCW - Total coliform count of beach water samples 11) TCS- Total coliform count of beach sediment samples (12) FCW - Faecal coliform count of beach water samples (13) FCS- Faecal coliform count of beach sand samples (14) AWAeromonas hydrophila concentration in beach water samples (15) EW- Enterococci concentration in beach water samples (16) SAS- Staphylococcus aureus counts of beach sediment samples (17) $T(W)$ - Beach water temperature in $O C$ (18) $D(W)$ - Dissolved oxygen in \% air saturation (19) DO(W) Dissolved oxygen in $\mathrm{mg} / \mathrm{L}(20) \mathrm{pH}(\mathrm{W})$ - measure of the activity of the hydrogen ion concentration of beach water sample (21) S(W)- Salinity (in ppt). 
are compared as they both are responsible for more than $50 \%$ of the variance. From the diagram it is observable that ES, TCPS, FCS, VSS, SAS all which are soil parameters weighed strongly in $\mathrm{PC} 1$ but negatively to the total variance observed in PC2. Observably for beach water, Enterococci (EW) appear to have an edge in that it weighed both strongly and positively in both first and second principal components unlike faecal coliforms (FCW) which weighed rather weakly in the first component and negatively in the second principal component.

The values of PCA can be sanitized by means of verimax rotation (Helena et al. 2000). Using this approach, varivalues and VFs are produced in which original variables participate more clearly. Following the transformation, the significant VFs extracted using the same criteria as that for PCA yielded a spread of high variance among V1-V6. Table 3 shows the first six VFs spanning $80.3 \%$ of the variance as opposed to $86.3 \%$ as explained by the same number of PCs. The implicit combination of parameters in PC1 and PC2 is further broken up to clearly delineate parameters that weigh strongly for beach water and sediment quality monitoring. Using this approach, samples are ordered along the $\mathrm{x}$-axis (Figure 4) in a similar but more compact way than was presented in Figure 4b. F1 and F2 are verimaxrotated PCs with a clearer picture of a cascade of traditional water quality parameters which weighted both strongly and positively among the two considered factors (using the same criteria used for the selection of PCs. Observably from Figure $4 \mathrm{~b}$, delineated parameters which weigh strongly for beach water were enterococci (EW) and faecal coliforms (FCW). The observation for beach water samples is consistent with available literature on the appropriateness of enterococci (EW) and faecal coliforms for surface water quality monitoring (Barrell et al. 2000). An approach to beach water quality monitoring may be that which at least focuses on the combination of EW and FCW for beach water quality monitoring.

On the other hand however, enterococci concentration in seawater (EW) weighed strongly in the first verifactor which was responsible for $28.9 \%$ of the total variance unlike faecal coliforms (FCW) which weighed strongly only in the second verifactor responsible for a lesser amount of variance (15.8\%). Suggestively, enterococci concentration in seawater thus emerged as an indicator of choice for BQM in Malaysia. Previous studies have reported that the risk to health increases in proportion to the amount of faecal pollution as measured by indicator organisms. In line with the findings of our study that validate enterococci for use as indicator organism in BQM, a number of studies (Fleisher et al., 1993; Kay et al. 1992; USEPA, 2011) also attest that the bacterial indicator most strongly associated with risk to health, particularly for marine coastal beaches seems to be the enterococci count. Barrell et al. (2000) argues that although faecal coliforms were also independently associated with illness in some studies, the apparent superiority of enterococci as indicators of health risk in both drinking and bathing waters remains undisputed. The study however places a doubt on the willingness of relevant agencies in a period of 20 years to replace the traditional coliform standard with the apparently superior indicator, enterococci as the primary routine microbiological test of water. Notwithstanding, in countries like Malaysia where there is currently no established beach water bacteriological monitoring program in place, a proactive approach for an envisioned BQM scheme will be an adoption of Enterococci as the choice parameter.

On the other hand, for beach sand delineated parameters; Staphylococcus aureus (SAS), faecal coliforms (FCS), enterococci (ES) and total plate count (TPCS) emerged with strong positive loadings significantly contributing to the variance following verimax rotation in factor analysis. This again highlights the importance of both to beach sand quality monitoring additionally, it is also suggested depending on the budget, an inclusion of SAS and TPCS as they generally may correlate with the levels of anthropogenic influence and subsequently contamination of coastal beach sand. Conditions that favor the persistence of autochthonous faecal indicator bacteria in coastal beach sand include increased protection from sunlight, buffered temperatures, nutrient availability, reduced osmotic stress, protection from predation by other microorganisms, a large surface area for biofilm development, and higher moisture and organic content from wave swash (Alm et al., 2003; Whitman et al. 2003; Heaney et al., 2009; Ishii et al. 2007; Beversdorf et al., 2007; WHO, 2003; Kinzelman et al. 2004; Yamahara et al., 2009). In the light of these factors, studies have thus shown that microbial contamination is higher in sand than in adjacent waters, as the sand behaves as a passive harbour for cumulative pollution (Oliveira \& Mendes, 1991, 1992; Oshiro \& Fujioka, 1995). This could subsequently become the reason for periodically high levels of bacteria in the adjacent water. Moreover, a hard and bind rule is not easy to achieve when making a case for guideline values of faecal indicator organisms in sand water because sand contamination is highly variable over short distances, making interpretation of results difficult (Figueras et al., 1992; Oshiro \& Fujioka, 1995).

Also, little is known about inter-linkages between sand contact activities and health effects and only a few studies have attempted relating sand contact activities to increased risk of illness among beachgoers (Marino et al., 1995; Bonilla et al. 2007, Heaney et al., 2009). Nonetheless, the importance of beach sand in relation to recreational health risks may be well underestimated particularly for tropical climates. WHO (2003) argues that the presence of indicator bacteria in beach sand and the relationship 
between their counts in beach sand and their counts in adjacent waters have comprised a significant area of research, with apparently contradictory results. The report also argued that the capacity of pathogens in beach sand to infect beach users remains undemonstrated, and the real extent of their threat to public health is unknown and that there is no evidence to support the establishment of a guideline value for index organisms or pathogenic microorganisms in beach sand. However, the studies whose findings formed the basis for these conclusions were largely conducted on temperate beaches. For example, all the citations referred to (Conseil Supérieur d'Hygiène Publique de France, (1990) (France), Signorile et al. (1992), Bonadonna et al. (2002) (Italy), Figueras et al. (1992), Ghinsberg et al. (1994) (Spain), Papadakis et al. (1997), Borrego et al. (1991) (Greece)\} are locations where daily ambient temperatures are by far lower than what obtains in the tropics. Conclusions drawn on occurrences or observation in temperate waters of the world may not present adequate representations of what obtains generally on the globe. Understandably however, studies that have focused on beach sand quality in tropical beaches are few. Hopefully, more studies will emerge in the future particularly in tropical climates that will explore this area of research. It is desired that such studies attempt to provide epidemiological evidence for health risks from exposure to sandy beaches while exploring possible dose-response relationships that associate the microbial quality of beach sand with infectious diseases.

Our findings provide meaningful evidence particularly as it relates to the correlation of Enterococci with pathogens and other non-microbial parameters. It also provides empirical data to validate the applicability of the enterococci indicator paradigm for BQM in Malaysia. The current study thus provides policy decision makers evidenced based approach to parameter streamlining for optimized beach sampling and sustainable bacteriological quality monitoring. Enterococci counts in beach water samples (EW) emerged with strong loadings and correlations in our analysis, thus signifying its appropriateness for use as indicator in BQM in the selected multi-beaches. The application of our findings could be up-scaled to the national level by relevant agencies charged with the mandate of coastal water management. A practical limitation however in its application for beach water quality analysis and beach profiling is the unavailability of similar studies in the country that employ this approach. This makes comparison difficult. To the best of our knowledge, this is the first study that uses a combination of multi-variate and multiparameter approach for the validation of Enterococci as indicator organism for bacteriological quality monitoring of recreational beach water quality in Malaysia. Hopefully studies will emerge in the future with a view to providing policy decision makers validated empirical data that correlates Enterococci with even a larger pool of pathogens and non-microbial parameters in recreational beaches in Malaysia.

\section{Conclusion}

Different multivariate statistical techniques were used to evaluate spatial variations of beach water quality and to validate enterococci as an appropriate indicator organism for BQM in Malaysia. Correlation analysis showed that enterococci correlated to more number of beach water and beach sand quality parameter tested in this study. A simple regression model generated in this study was able to predict with a maximum predictive success of $69.64 \%$ using just a combination of 5 parameters. Hierarchical clustering grouped 41 sampling locations into four clusters of similar water quality characteristics. The factor analysis/ principle component analysis resulted in significant data reduction and assisted in extracting the water quality parameter that weighed strongly in the observed variations in beach river water quality at the different sampled beaches. Although delineated parameters with significant weighing for beach water were enterococci (EW) and faecal coliforms (FCW), enterococci concentration in seawater presented stronger loadings and suggestively emerged as an appropriate indicator of choice for BQM in Malaysia. This study also illustrates the usefulness of multivariate statistical techniques for the validation of the use of enterococci as indicator organism in BQM.

\section{Methods}

\section{Study area}

The beaches considered for sampling during this study are locations selected as part of a nation-wide pathogen monitoring program under the auspices of the School of Bioscience and Biotechnology, Faculty of Science and Technology, Universiti Kebangsaan Malaysia. The samples were taken at the public beaches at Kelantan (Figure 5). Pantai Seri Tujuh lies on the border of Thailand and Kelantan at Kampung Tujuh in Turnpat, about $7 \mathrm{~km}$ from Kota Bharu. The coastline fringes the South-China Sea en-route to Pantai Seri Tujuh. Tok Bali Beach is located near the mouth of Semerak Canal. Irama Beach (Beach of Melody) is a wide and long sandy beach situated in Bachok district. It is about $25 \mathrm{~km}$ south of Kota Bharu and faces the South China Sea with. This beach has over the past decade suffered from coastal erosion. Pantai Cahaya Bulan is located some $10 \mathrm{~km}$ from Kota Bharu town. Spanning about 1.2 kilometers, this beach is famously known as the landing area for the Japanese-British war in the formative years of Malaysia. Two important fishing villages in the East Coast of Malaysia are Sabak Beach (approx. $14 \mathrm{~km}$ from Kota Bharu) and Kuala Besar (15 km from Kota Bharu). 


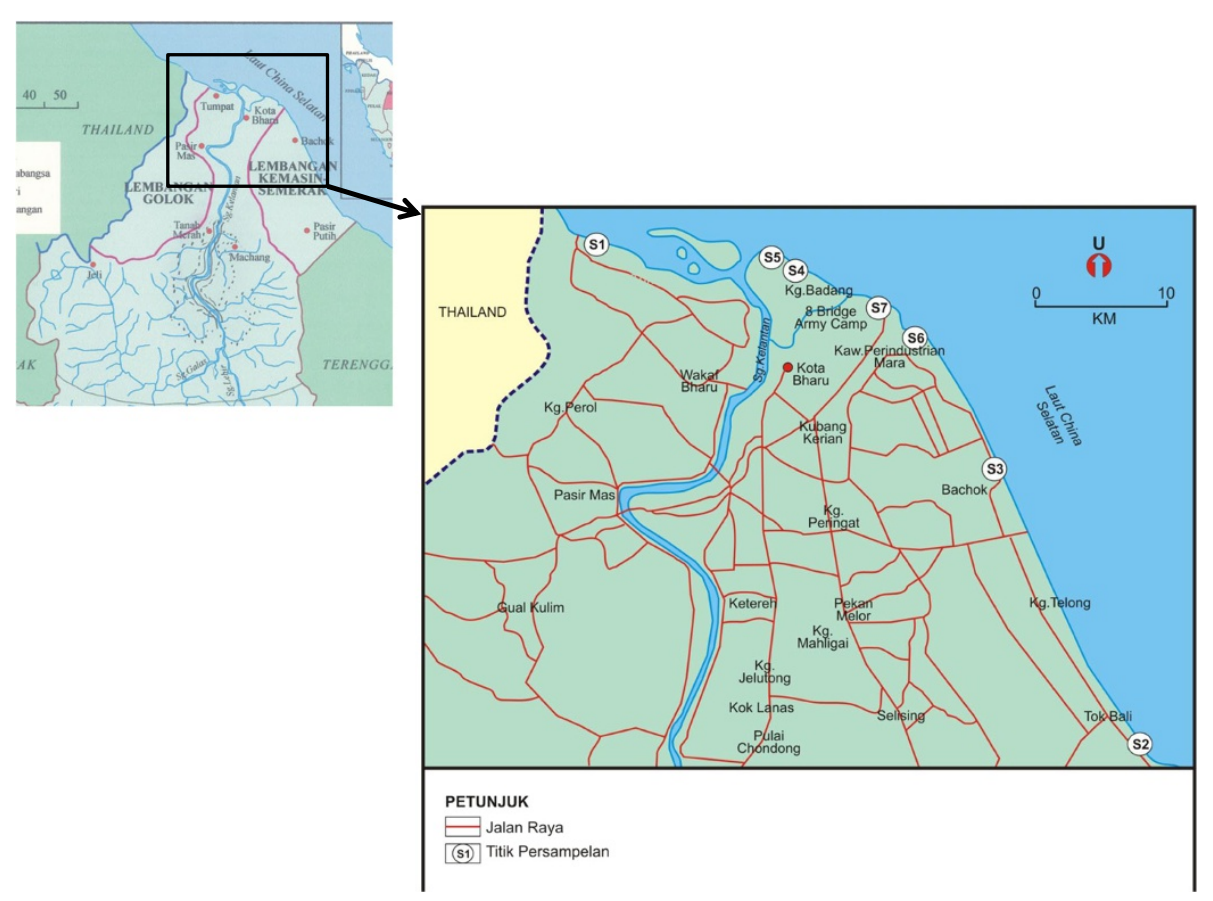

Figure 5 Sampling stations considered for this study. S1-Pantai Sri Tujuh (SRI7), S2-Tok Bali, S3-Pantai Irama, S4- Pantai Cahaya Bulan (PCB), S5-Kuala Besar, S6-Pantai Senuk, S7- Pantai Sabak.

\section{Sample collection}

Sterile glass bottles $(1,000 \mathrm{ml})$ were used to collect water samples in duplicates, while sterile disposable containers $(500 \mathrm{ml})$ were used to collect sediments. Samples were stored on ice until analyzed, usually within $4 \mathrm{~h}$ after collection.

\section{Analysis of physicochemical parameters}

Physico-chemical parameters were measured on site. Samples were stirred gently and stable readings were recorded as described by Sangiorgio et al. (2010) using YSI 556 hand-held multi-probe that simultaneously measures Dissolved Oxygen (\% and g/L), pH, Conductivity $(\mathrm{mS} / \mathrm{cm})$, TDS $(\mathrm{g} / \mathrm{L})$, Salinity $(\mathrm{ppt})$ and Temperature $\left({ }^{\circ} \mathrm{C}\right)$. Readings were recorded in triplicates.

\section{Enumeration of Enterococci and other pathogens}

Enterococci were recovered from seawater using membrane filtration method using Slanetz and Bartley $(\mathrm{S}+\mathrm{B})$ culture media as previously described (Dada et al., 2013). Counts were recorded as $\mathrm{cfu} / \mathrm{ml}$. Isolates that were catalase negative, able to grow in $6.5 \% \mathrm{NaCl}$ and to hydrolyze esculin in the presence of $40 \%$ bile salts were considered as presumptive Enterococci. Vibrio was enumerated using Thiosulfate Citrate Bile salt Sucrose (TCBS) agar, a growth medium generally used for their detection as described (Cañigral et al., 2010). Aeromonas hydrophila was recovered using modified Rimler Shotts agar. The media consisted of L-lysine ( $5 \mathrm{~g} / \mathrm{L})$, L-ornithine
(6.5 g/L), maltose $(7.5 \mathrm{~g} / \mathrm{L})$, sodium thiosulphate $(6.8 \mathrm{~g} / \mathrm{L})$, L-cysteine $(0.3 \mathrm{~g} / \mathrm{L})$, ferric ammonium citrate $(0.8 \mathrm{~g} / \mathrm{L})$, bile salt $(5 \mathrm{~g} / \mathrm{L})$, yeast extract $(3 \mathrm{~g} / \mathrm{L})$, bacto agar $(13 \mathrm{~g} / \mathrm{L})$, bromothymol blue $(0.03 \mathrm{~g} / \mathrm{L})$ all prepared in a litre of distilled water. Plates were incubated at $37^{\circ} \mathrm{C}$ for $24-48 \mathrm{~h}$.

For Staphylococcus aureus, manitol salt agar at $35^{\circ} \mathrm{C} \pm$ $2^{\circ} \mathrm{C}$ for $24 \mathrm{~h}$ was used (Goodwin et al. 2012). After incubation, yellow colonies were counted as presumptive $S$. aureus. For confirmation, from each sample lot representative colonies of $S$. aureus were chosen and subjected to the coagulase test. The total viable bacterial and coliform populations were enumerated in seawater and sediment samples by spread plate method using nutrient agar medium (Himedia) with $2.5 \% \mathrm{NaCl}$ supplementation and chromogenic coliform agar respectively. For faecal coliform counts, the same agar was used as for total coliform except that plates were incubated at elevated temperatures of $44.5^{\circ} \mathrm{C}$ (APHA, 1999). Aliquots of seawater samples were serially diluted with sterile saline and $100 \mathrm{ul}$ of samples were spread on nutrient agar medium. For sand samples, a different approach was used. Each sediment samples were weighed, added in to sterile saline $(1: 100)$ and thoroughly shaken to ensure that all attached microbes are disentangled from the sediment. Subsequently, the procedure used for enumeration of seawater was followed for total viable count using the supernatant from the sand-saline suspension. Experiments were performed in triplicates and numbers of bacterial colonies were expressed in $\log \mathrm{CFU} / \mathrm{g}$ of beach sand and $\log \mathrm{CFU} / 100 \mathrm{ml}$ 
of seawater. Specific media (Salmonella-Shigella agar) was used for identification of Salmonella typhi (Wells and Butterfield, 1997). All the plates were incubated in triplicates at $37^{\circ} \mathrm{C}$ for $24-48 \mathrm{~h}$.

\section{Descriptive statistical analyses}

The purpose of descriptive statistics was to explore (i) general frequencies of indicator organism and pathogen count at the study sites and ii) to present a geometric mean-based correlation analyses to explore relationships between Enterococci and other microbial and nonmicrobial parameters measured in the study. A two-way ANOVA was done with each row in the tables generated representing a different time point such that matched values are stacked together into a sub-column. The experimental design selected for the analysis was such that the factor that defined the columns was the parameters considered and the factor that defined the rows was the respective beach studied. Multiple comparisons were also conducted involving comparisons within each column, comparing rows (simple effects within columns). Using this approach, for each column, comparisons of cell mean was made with every other cell mean on each column. Turkey's test was used to correct for the multiple comparisons and to compute confidence intervals (CIs) and significance. Column-wise significance and confidence levels were taken as 0.05 and $95 \%$ respectively. All generated data were fed into a grouped data format and column statistics involving correlations made using the Pearson's Correlation rank.

\section{Regression analysis}

Following the test for associations between recorded parameters (considered in pairs) using the Pearson Correlation rank analysis, multiple linear regression was also conducted comparing one dependent and multiple independent variables. Using a more or less descriptive approach, the purpose of the multiple linear regressions was to highlight a best fit model that could function in predicting enterococci concentrations as it relates to other parameters in beach water and sand samples. As described by Goodwin et al. (2012), model selection was based on p-values for the coefficient (apha $=0.05$ ). Non-significant terms were sequentially removed from the model using stepwise method. The formula used for regression analysis in our study was adapted after Camdevyren et al. (2005) and is stated as:

$$
E W=a+b^{1} s^{1}+b^{1} s^{1}+b^{1} s^{1}+b^{1} s^{1}+e
$$

Where $\mathrm{a}$ is the constant term, $\mathrm{b}^{\mathrm{k}}$ is the regression coefficient of values of parameter $s^{k}$, e is the error term of the model. In this study, $t$-test was used in testing the regression coefficients. Analysis of variance (ANOVA) was also conducted for the model with $\mathrm{p}$ taken as significant at values less than 0.05 .

\section{Multivariate statistical methods}

As suggested by Shrestha and Kazama (2007), the Kolmogorov-Smirnov (K-S) statistics were used for the purpose of confirming the goodness-of-fit of the data to log normal distribution at a 95\% confidence level. Four major multivariate statistical methods were used in the multi-beach study: cluster analysis (CA), principal component analysis (PCA), factor analysis (FA) and discriminate analysis (DA). The purpose of the application of multivariate statistical analysis to our data was primarily to help in the interpretation of complex data matrices and to ultimately present a more meaningful understanding of water quality of the studied beaches. This unarguably offers policy decision makers in their efforts aimed at sustainable management of coastal beach water resources (Adams et al., 2001, Alberto et al., 2001; Simeonov et al., 2003; Singh et al., 2004, 2005). Data generated for all the parameters were $\mathrm{z}$-scale transformed before used in line with the suggestions of Liu et al. (2003) and Simeonov et al. (2003). This transformation was necessary to prevent misclassifications arising from the different orders of magnitude of both numerical values and variance of the parameters analyzed. Softwares used in the analysis are Minitab 16, SPSS 20 and Graph Prism.

\section{Cluster analysis}

The major reason why this analysis was done was to assemble the sampled sites based on the characteristics they possess. Cluster analyses is an unsupervised pattern recognition method that divides a large group of cases into smaller groups or clusters of relatively similar cases that are dissimilar to other groups (Zhou et al., 2007). One of the most common approach used in CA is Hierarchical agglomerative, a method typified by its provision of similarity relationships between any one sample and the entire data set. Usually, it begins with each case in a separate cluster and joins the clusters together step by step until only one cluster remains (Lattin et al., 2003; McKenna, 2003). The output is usually illustrated by a dendrogram which presents the groups and their proximity pictorially alongside with a reduction in dimensionality of the initial data fed into the analyses (McKenna, 2003). During the analyses, Euclidean distances taken as a measure of similarity using the Ward's approach was adopted for the hierarchical agglomerative CA.

\section{Principal component analysis}

The purpose of PCA in the study was to transform the original variables into new, uncorrelated variables (axes), called the principal components, which are linear combinations of the original variables. Using this analysis, a 
more purposeful approach was achieved for detailing the source of variation in the data (Sarbu and Pop, 2005). Other important goals achievable through the principal component analyses are substantial data reduction while still retaining original information (Helena et al., 2000). The PCA is described by the formula:

$$
Z_{i j}=a_{i 1} x_{1 j}+a_{i 1} x_{1 j}+a_{i 1} x_{1 j}+a_{i 1} x_{1 j}+a_{i 1} x_{1 j} \ldots . a_{i m} x_{m j}
$$

where $\mathrm{z}$ is the component score, $\mathrm{a}$ is the component loading, $\mathrm{x}$ the measured value of variable, $\mathrm{i}$ is the component number, $j$ the sample number and $m$ the total number of variables.

\section{Factor analyses}

Factor analysis was done after Principal Component Analyses. Factor analyses (FA) is particularly applicable in water quality monitoring where series of approaches consisting of varied mix of indicator organism and pathogen detection approaches are used. FAs help to reduce the contribution of less significant variables to simplify even more of the data structure coming from PCA. To run this analysis, the axis defined by PCA was carefully rotated with the subsequent formation of new variables termed as varifactors (VF) (Vega et al., 1998; Helena et al., 2000). In other words, the contribution of variables with minor significance is further decreased as only significant PCs extracted from PCA are verimax rotated to generate VFs in the FA. FA is based on the premise that a small number of factors will usually account for approximately the same amount of information as do the much larger set of original observations (Brumelis et al., 2000; Singh et al., 2004, 2005; Love et al., 2004; Abdul-Wahab et al., 2005). Factor analysis is given by the formula:

$$
Z_{i j}=a_{i 1 f} f_{1 j}+a_{i 1} f_{1 j}+a_{i 1} f_{1 j}+a_{i 1} f_{1 j}+a_{i 1} f_{1 j} \ldots . a_{i m} f_{m j}+e_{f i}
$$

where $\mathrm{z}$ is the measured variable, $\mathrm{a}$ is the factor loading, $\mathrm{f}$ is the factor score, $\mathrm{e}$ is the residual term accounting for errors or other source of variation, i the sample number and $\mathrm{m}$ the total number of factors.

\section{Competing interests}

All authors declare that they have no competing interests.

\section{Authors' contributions}

ACD conceived the study, carried out the microbiological analysis, analysed the data and wrote the manuscript. AA and GU provided direction on the study design, contributed to sample collection and microbiological analysis. LYH provided direction on the study design. All authors contributed to the general content and structure of the final manuscript. All authors read and approved the final manuscript.

\section{Acknowledgements}

The corresponding author is in receipt of an Education Tax Fund PhD scholarship. Thanks to Encik Alias, Rahimi Hamid, Aisya. Zulkifli and Zainal Lutfi for assistance during sample collection and laboratory analysis. Financial support for sampling and laboratory analysis from the Science Fund grant (04-01-02-SF0754) under the auspices of the School of Bioscience and Biotechnology, FST, UKM is appreciated. Institute of Ecology and Environmental Studies, Obafemi Awolowo University, Ile-Ife, Nigeria gratefully granted study leave for the research.

\section{Author details}

${ }^{1}$ School of Biosciences and Biotechnology, Faculty of Science \& Technology, Universiti Kebangsaan Malaysia, 43600, UKM Bangi, Malaysia. ${ }^{2}$ Institute of Ecology and Environmental Studies, Obafemi Awlowo University, lle-Ife, Nigeria. ${ }^{3}$ School of Environmental \& Natural Resource Sciences, Faculty of Science \& Technology, Universiti Kebangsaan Malaysia, 43600, UKM Bangi, Malaysia. ${ }^{4}$ School of Chemical Sciences and Food Technology, Faculty of Science \& Technology, Universiti Kebangsaan Malaysia, 43600, UKM Bangi, Malaysia.

Received: 9 May 2013 Accepted: 26 August 2013

Published: 30 August 2013

\section{References}

Abdelzaher AM, Wright ME, Ortega C, Solo-Gabriele HM, Miller G, Elmir S et al (2010) Presence of Pathogens and Indicator Microbes at a Non-Point Source Subtropical Recreational Marine Beach. Appl Environ Microbiol 76(3):724-732. doi:10.1128/Aem.02127-09

Abdul-Wahab SA, Bakheit CS, Al-Alawi SM (2005) Principal component and multiple regression analysis in modelling of ground-level ozone and factors affecting its concentrations. Environ Model Software 20(10):1263-1271

Adams S, Titus R, Pietersen K, Tredoux G, Harris C (2001) Hydrochemical characteristics of aquifers near Sutherland in the Western Karoo, South Africa. J Hydrol 241(1):91-103

Alberto WD, del Pilar DM, Valeria AM, Fabiana PS, Cecilia HA, de los Ángeles BM (2001) Pattern Recognition Techniques for the Evaluation of Spatial and Temporal Variations in Water Quality. A Case Study: Suquía River Basin (Córdoba-Argentina). Water Res 35(12):2881-2894

American Public Health Association (1999) Standard Methods for the Examination of Water and Waste Water, 20th edn. American Public Health Association, Washington DC, USA

Barrell R, Hunter P, Nichols G (2000) Microbiological standards for water and their relationship to health risk. Commun Dis Public Health 3(1):8-13

Beversdorf L, Bornstein-Forst S, McLellan S (2007) The potential for beach sand to serve as a reservoir for Escherichia coli and the physical influences on cell die-off. J Appl Microbiol 102(5):1372-1381

Bonadonna L, Briancesco R, Cataldo C, Di Girolamo I (2002) Microbiological quality of seaside sands: a beach in Latium]. Igiene e sanità pubblica 58(1-2):43

Bonilla TD, Nowosielski K, Cuvelier M, Hartz A, Green M, Esiobu N et al (2007) Prevalence and distribution of fecal indicator organisms in South Florida beach sand and preliminary assessment of health effects associated with beach sand exposure. Mar Pollut Bull 54(9):1472-1482

Borrego JJ, Romero P, Marino F (1991) Epidemiological study on bathers from selected beaches in Malaga. United Nations Environment Programme, Mediterranean Action Plan (MAP Technical Reports Series No. 53), Athens, pp 1-27

Brūmelis G, Lapina L, Nikodemus O, Tabors G (2000) Use of an artificial model of monitoring data to aid interpretation of principal component analysis. Environ Model Software 15(8):755-763

Calderon RL, Mood EW, Dufour AP (1991) Health effects of swimmers and nonpoint sources of contaminated waters. Int J Env Health Res 1:21-31

Çamdevýren H, Demýr N, Kanik A, Keskýn S (2005) Use of principal component scores in multiple linear regression models for prediction of Chlorophyll in reservoirs. Ecol Model 181(4):581-589

Cañigral I, Moreno Y, Alonso JL, González A, Ferrús MA (2010) Detection of Vibrio vulnificus in seafood, seawater and wastewater samples from a Mediterranean coastal area. Microbiol Res 165(8):657-664

Casas V, Sobrepeña G, Rodriguez-Mueller B, AhTye J, Maloy SR (2011) Bacteriophageencoded shiga toxin gene in atypical bacterial host. Gut Pathogens 3(1):1-7

Conseil Supérieur d'Hygiène Publique de France (1990) Qualité microbiologique des sables: essai d'un nouveau précédé de désinfection. [Microbiological quality of sea sand: a trial of a new disinfection protocol]. Paris 
Curiel-Ayala F, Quiñones-Ramírez E, Pless R, González-Jasso E (2012) Comparative studies on Enterococcus, Clostridium perfringens and Staphylococcus aureus as quality indicators in tropical seawater at a Pacific Mexican beach resort. Mar Pollut Bull 4(10):2193-8

Dada AC, Asmat A, Gires U, Heng LY, Deborah BO (2012) Bacteriological monitoring and sustainable management of beach water quality in Malaysia: problems and prospects. Global J Health Sci 4(3):126

Dada AC, Ahmad A, Usup G, Heng LY (2013) Speciation and antimicrobial resistance of Enterococci isolated from recreational beaches in Malaysia. Environ Monit Assess 185(2):1583-1599. doi:10.1007/s10661-012-2653-6

Debacker V, Jauniaux T, Coignoul F, Bouquegneau J-M (2000) Heavy Metals Contamination and Body Condition of Wintering Guillemots (Uria aalge) at the Belgian Coast from 1993 to 1998. Environ Res 84(3):310-317

DOE (2006) Department of Environmental Malaysia environmental quality report 2006 Impak, Kuala Lumpur: Ministry of Science. Technol Environ 3:1-16

El-Shenawy MA (2005) Staphylococcus aureus and fecal indicators in Egyptian coastal waters of Aqaba Gulf, Suez Gulf, and Red Sea. Egypt J Aquatic Res 31(2):113-124

Enns AA, Vogel LJ, Abdelzaher AM, Solo-Gabriele HM, Plano LRW, Gidley ML, Phillips MC, Klaus JS, Piggot AM, Feng Z, Reniers AJHM, Haus BK, Elmir SM, Zhang Y, Jimenez NH, Abdel-Mottaleb N, Schoor ME, Brown A, Khan SQ, Dameron AS, Salazar NC, Fleming LE (2012) Spatial and temporal variation in indicator microbe sampling is influential in beach management decisions. Water Res 46(7):2237-2246

Facchinelli A, Sacchi E, Mallen L (2001) Multivariate statistical and GIS-based approach to identify heavy metal sources in soils. Environ Pollut 114(3):313-324

Figueras MJ, Guarro J, Soler L, Inza I, Polo F (1992) Estudio piloto sobre la contamination de las playas del litoral Catalan. [A pilot study on the contamination of Catalounian beaches.]. Proceedings of the $1^{\circ}$ Congreso Nacional del Medio Ambiente, Madrid

Fleisher J, Jones F, Kay D, Stanwell-Smith R, Wyer M, Morano R (1993) Water and non-water-related risk factors for gastroenteritis among bathers exposed to sewage-contaminated marine waters. Int J Epidemiol 22(4):698-708

Ghinsberg R, Bar Dov L, Rogol M, Sheinberg Y, Nitzan Y (1994) Monitoring of selected bacteria and fungi in sand and sea water along the Tel Aviv coast. Microbios 77(310):29

Goodwin KD, McNay M, Cao Y, Ebentier D, Madison M, Griffith JF (2012) A multi-beach study of Staphylococcus aureus, MRSA, and enterococci in seawater and beach sand. Water Res 46(13):4195-4207

Graham JL, Loftin KA, Kamman N (2009) Monitoring Recreational Freshwaters: State Monitoring Programs for Cyanobacterial Toxins in Recreational Freshwaters of the United States. LakeLine 29:18-24

Grant SB, Sanders B, Boehm A, Redman J, Kim J, Mrše R et al (2001) Generation of enterococci bacteria in a coastal saltwater marsh and its impact on surf zone water quality. Environ Sci Technol 35(12):2407-2416

Håkanson L, Malmaeus JM, Bodemar U, Gerhardt V (2003) Coefficients of variation for chlorophyll, green algae, diatoms, cryptophytes and blue-greens in rivers as a basis for predictive modelling and aquatic management. Ecol Mod 169:179-196

Heaney CD, Sams E, Wing S, Marshall S, Brenner K, Dufour AP et al (2009) Contact with beach sand among beachgoers and risk of illness. Am J Epidemiol 170(2):164-172

Helena B, Pardo R, Vega M, Barrado E, Fernandez JM, Fernandez L (2000) Temporal evolution of groundwater composition in an alluvial aquifer (Pisuerga River, Spain) by principal component analysis. Water Res 34(3):807-816

Ishii S, Hansen DL, Hicks RE, Sadowsky MJ (2007) Beach sand and sediments are temporal sinks and sources of Escherichia coli in Lake Superior. Environ Sci Technol 41(7):2203-2209

Jackson JE (2005) A user's guide to principal components (Vol. 244). Wiley-Interscience Johnstone D (2007) Water Quality Standards and Developing Nations. M.Sc Lecture Series, Oxford University Centre for the Environment, Oxford, United Kingdom

Kay D,JF (1992) Recreational water quality. PHLS Microbiol Dig 9:125-128

Kinzelman J, McLellan S, Daniels A, Cashin S, Singh A, Gradus S et al (2004) Non-point source pollution: determination of replication versus persistence of Escherichia coli in surface water and sediments with correlation of levels to readily measurable environmental parameters. J Water Health 2:103-114

Kuylenstierna JL, Björklund G, Najlis P (2009) Sustainable water future with global implications: everyone's responsibility. Nat Resour Forum 21:181-190

Lattin JM, Carroll JD, Green PE (2003) Analyzing multivariate data. Thomson Brooks/Cole, Pacific Grove, CA
Lee J-Y, Cheon J-Y, Lee K-K, Lee S-Y, Lee M-H (2001) Statistical evaluation of geochemical parameter distribution in a ground water system contaminated with petroleum hydrocarbons. J Environ Qual 30(5):1548-1563

Liu JZ, Shan ZY, Zhang LD, Sahgal V, Brown RW, Yue GH (2003) Human brain activation during sustained and intermittent submaximal fatigue muscle contractions: an FMRI study. J Neurophysiol 90:300-312

Love D, Hallbauer D, Amos A, Hranova R (2004) Factor analysis as a tool in groundwater quality management: two southern African case studies. Phys Chem Earth, Parts A/B/C 29(15):1135-1143

Marino F, Morinigo M, Martinez-Manzanares E, Borrego J (1995) Microbiologicalepidemiological study of selected marine beaches in Malaga (Spain). Water Sci Technol 31(5):5-9

McKenna J Jr (2003) An enhanced cluster analysis program with bootstrap significance testing for ecological community analysis. Environ Model Software 18(3):205-220

Miller MA, Byrne BA, Jang SS, Dodd EM, Dorfmeier E, Harris MD et al (2010) Enteric bacterial pathogen detection in southern sea otters (Enhydra lutris nereis) is associated with coastal urbanization and freshwater runoff. Vet Res 41(1):01-01

Novais C, Coque TM, Ferreira H, Sousa JC, Peixe L (2005) Environmental contamination with vancomycin-resistant enterococci from hospital sewage in Portugal. Appl Environ Microbiol 71(6):3364-3368

Olapade OA, Depas MM, Jensen ET, McLellan SL (2006) Microbial communities and fecal indicator bacteria associated with Cladophora mats on beach sites along Lake Michigan shores. Appl Environ Microbiol 72(3):1932-1938

Oliveira JS, Mendes BS (1991) Poluicao das praias e zonas litorais: Medidas cauterales e normas de qualidade. Reuniaö o sobre a Gestaö Municipal e a Gestaö da Agua. [Pollution of beaches and coastal areas: preventive measures and quality standards. Meeting on Management of Municipalities and Water Management]. Cascais, Portuguese Association of Water Resources (APRH)/ Municipality Service of Water and Sanitation (SMAS)

Oliveira JS, Mendes BS (1992) Qualidade da Agua do Litoral Portugues. [Water quality in Portugal]. Proceedings of the First Water Congress, Lisbon. Association of Water Resources (APRH), Lisbon, Portuguese, pp 155-179

Ongley ED (1997) Matching water quality programmes to management needs in developing countries: the challenge of programme modernization. Eur Water Pollut Contr 7(4):43-48

Oshiro R, Fujioka R (1995) Sand, soil, and pigeon droppings: sources of indicator bacteria in the waters of Hanauma Bay, Oahu, Hawaii. Water Sci Technol 31(5):251-254

Papadakis J, Mavridou A, Richardson S, Lampiri M, Marcelou U (1997) Bather-related microbial and yeast populations in sand and seawater. Water Res 31(4):799-804

Phillips MC, Solo-Gabriele HM, Piggot AM, Klaus JS, Zhang Y (2011) Relationships between sand and water quality at recreational beaches. Water Res 45(20):6763-6769

Praveena SM, Siraj SS, Suleiman AK, Aris A (2011) A brush up on water quality studies of Port Dickson, Malaysia. J Res J Environ Sci 5(12):841-849

Reghunath R, Murthy T, Raghavan B (2002) The utility of multivariate statistical techniques in hydrogeochemical studies: an example from Karnataka, India. Water Res 36(10):2437-2442

Regulations TBWC (1991) Statutory Instrument 1991. No. 1597. HMSO, London Reimann C, Banks D (2004) Setting action levels for drinking water: Are we protecting our health or our economy (or our backs!)? SciTotal Environ 332:13-21

Salas HJ, Robinson K (2006) Proposed protocol for epidemiological investigatons in recreaional bathing waters for Latin America and the Caribbean. Asociación Interamericana de Ingeniería Sanitaria y Ambiental. XXX Congreso Interamericano de Ingeniería Sanitaría y Ambiental. 26 al 30 de noviembre de 2006, Punta del Este - Uruguay. In F. Curiel-Ayala, E.I. Quiñones-Ramírez, R.C. Pless, Eva GonzálezJasso 2012 Comparative studies on Enterococcus, Clostridium perfringens and Staphylococcus aureus as quality indicators in tropical seawater at a Pacific Mexican beach resort. Mar Pollut Bull 64(10):2193-2198

Sangiorgio F, Glazier DS, Mancinelli G, Basset A (2010) How can habitat size influence leaf litter decomposition in five mid-Appalachian springs (USA)? The importance of the structure of the detritivorous guild. Hydrobiologia 654(1):227-236

Sarbu C, Pop H (2005) Principal component analysis versus fuzzy principal component analysis a case study: the quality of danube water (1985-1996). Talanta 65(5):1215-1220

Selvakumar A, Borst M (2006) Variation of microorganism concentrations in urban stormwater runoff with land use and seasons. J Water Health 4(1):109-124

Shah AH, Abdelzaher AM, Phillips M, Hernandez R, Solo-Gabriele HM, Kish J, Scorzetti G, Fell JW, Diaz MR, Scott TM, Lukasik J, Harwood VJ, McQuaig S, 
Shrestha S, Kazama F (2007) Assessment of surface water quality using multivariate statistical techniques: A case study of the Fuji river basin, Japan. Environ Model Software 22(4):464-475

Shuval H (2003) Estimating the global burden of thalassogenic diseases: human infectious diseases caused by wastewater pollution of the marine environment. J Water Health 1:53-54

Signorile G, Montagna MT, Sena G, Cavallo RA (1992) Bacteriological surveys in waters and sands of Taranto coastal areas. Ig Mod 98:475-483

Simeonov V, Stratis J, Samara C, Zachariadis G, Voutsa D, Anthemidis A et al (2003) Assessment of the surface water quality in Northern Greece. Water Res 37(17):4119-4124

Simeonov V, Simeonov P, Tsitouridou R (2004) Chemometric quality assessment of surface waters: two case studies. Chem Eng Ecol 11(6):449-469

Singh KP, Malik A, Mohan D, Sinha S (2004) Multivariate statistical techniques for the evaluation of spatial and temporal variations in water quality of Gomti River (India): A case study. Water Res 38(18):3980-3992

Singh KP, Malik A, Sinha S (2005) Water quality assessment and apportionment of pollution sources of Gomti river (India) using multivariate statistical techniques_-a case study. Anal Chim Acta 538(1):355-374

Sinigalliano CD, Fleisher JM, Gidley ML, Solo-Gabriele HM, Shibata T, Plano LR et al (2010) Traditional and molecular analyses for fecal indicator bacteria in non-point source subtropical recreational marine waters. Water Res 44(13):3763-3772

Terrado M, Barceló D, Tauler R (2006) Identification and distribution of contamination sources in the Ebro river basin by chemometrics modelling coupled to geographical information systems. Talanta 70(4):691-704

USEPA (2004) Implementation Guidance for Ambient Water Quality Criteria for Bacteria. US Environmental Protection Agency, EPA-823-B-04-002

USEPA (2011) Water: Monitoring \& Assessment. Environmental Protection AgencyRetrieved October 18th, 2011., http://water.epa.gov/type/rsl/ monitoring/vms511.cfm

Vega M, Pardo R, Barrado E, Debán L (1998) Assessment of seasonal and polluting effects on the quality of river water by exploratory data analysis. Water Res 32(12):3581-3592

Wells J, Butterfield J (1997) Salmonella contamination associated with bacterial soft rot of fresh fruits and vegetables in the marketplace. Plant Dis 81(8):867-872

Wheeler-Alm E, Burke J, Spain A (2003) Fecal indicator bacteria are abundant in wet sand at freshwater beaches. Water Res 37(16):3978-3982

Whitman RL, Nevers MB (2003) Foreshore sand as a source of Escherichia coli in nearshore water of a Lake Michigan beach. Appl Environ Microbiol 69(9):5555-5562

WHO (2003) Guidelines for Safe Recreational Water Environments: Microbial Aspects of Beach Sand Quality. World Health OrganizationGeneva, Switzerland, pp 118-127

Wiedenmann A, Krüger P, Dietz K, López-Pila JM, Szewzyk R, Botzenhart K (2006) A randomized controlled trial assessing infectious disease risks from bathing in fresh recreational waters in relation to the concentration of Escherichia coli, intestinal enterococci, Clostridium perfringens, and somatic coliphages. Environ Health Perspect 114(2):228

Yamahara KM, Walters SP, Boehm AB (2009) Growth of enterococci in unaltered, unseeded beach sands subjected to tidal wetting. Appl Environ Microbiol 75(6):1517-1524

Yamahara KM, Sassoubre LM, Goodwin KD, Boehm AB (2012) Occurrence and persistence of human pathogens and indicator organisms in beach sands along the California coast. Appl Env Microbiol 78(6):1733-1745

Yoder JS, Blackburn BG, Craun GF, Hill V, Levy DA, Chen N et al (2004) Surveillance for waterborne-disease outbreaks associated with recreational water-United States, 2001-2002. MMWR Surveill Summ 53(8):1-22

Zhou F, Liu Y, Guo H (2007) Application of multivariate statistical methods to water quality assessment of the watercourses in Northwestern New Territories, Hong Kong. Environ Monit Assess 132(1-3):1-13

doi:10.1186/2193-1801-2-425

Cite this article as: Ahmad et al:: Validation of the Enterococci indicator for bacteriological quality monitoring of beaches in Malaysia using a multivariate approach. SpringerPlus 2013 2:425. 